\title{
Libro de Informes I. Calificación crediticia de los sujetos de crédito, Sucursal La Piedad, Michoacán, Banco Nacional de México, 1905-1907
}

\author{
Gladys Lizama Silva* \\ UNIVERSIDAD DE GUADALAJARA
}

\section{LA FUENTE DOCUMENTAL}

1 Libro de Informes, 1905-1907, es un volumen de grandes dimensiones parecido a los libros de contabilidad de la época (véase imagen 1), de unos $48 \mathrm{~cm}$ de largo por 25 de ancho, con 211 fojas de papel blanco muy resistente, que fueron escritas a máquina por un solo lado antes de ser encuadernadas con un sistema de pastas duras unidas con varillas y pequeñas trabes de metal. El volumen conserva la memoria escrita de los perfiles económico y moral de los sujetos de crédito que fueron investigados por R. G. Dun y Cía., ${ }^{1}$ que envió solicitudes de información o entrevistó a dichos individuos y a otros más que podían otorgar informes en las mismas fechas. ${ }^{2}$ Está muy bien conservado y puede consultarse en el Archivo del Banco Nacional de México, ubicado en la Ciudad de México.

*gladysli@cencar.udg.mx

Departamento de Estudios Sociourbanos, Liceo núm. 210, Planta Alta, Guadalajara, Jalisco, México, Agradezco el apoyo en la captura de información del estudiante de Licenciatura en Historia Ernesto Ochoa Valdez.

${ }^{1}$ D\&B llegó a México, con una corresponsalía en 1897. Más de un siglo después, Dun \& Bradstreet de México es hoy la más importante empresa de su tipo en el país, con oficinas en la Ciudad de México, Guadalajara, Monterrey, Puebla y Veracruz. Dun \& Bradstreet es el líder mundial en proporcionar información comercial para la toma de decisiones de crédito, mercadotecnia o mercadeo, y compras. Véase la siguiente liga: http://www.dnbmex.com.mx/esp_about.asp

${ }^{2}$ El libro está depositado en el Archivo del Banco Nacional de México en la capital de la república. Existen dos libros semejantes de la Sucursal Zamora, Michoacán, que han sido trabajados y analizados para otras publicaciones. 
IMAgEN I. Portada del Libro de Informes 1, Sucursal La Piedad del Banco Nacional de México
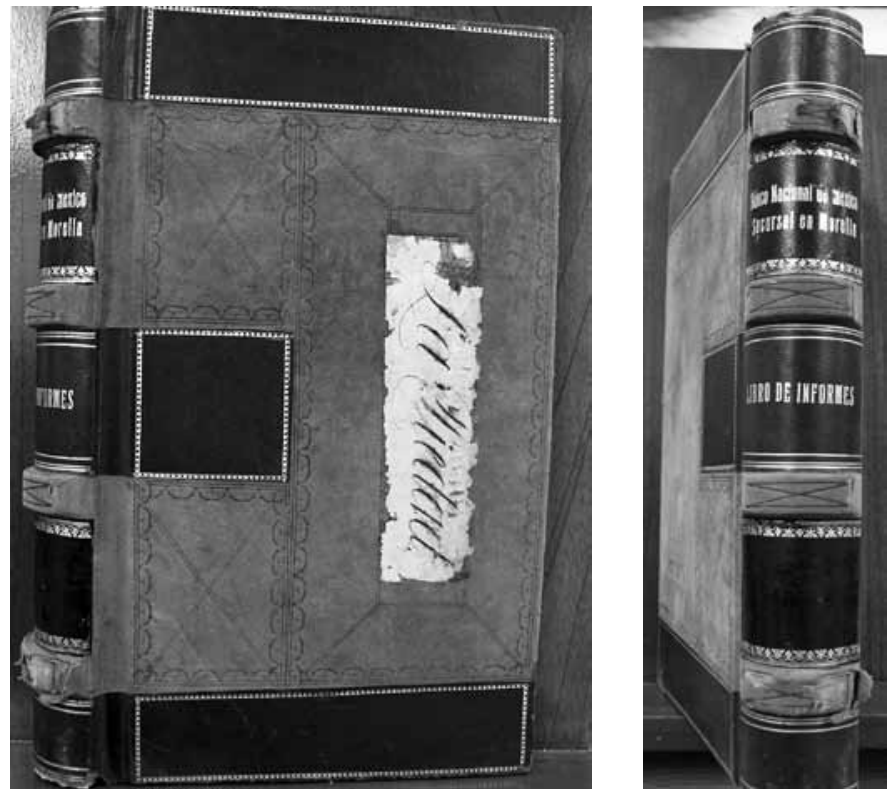

Fuente: Archivo Banco Nacional de México, Libro de Informes, Sucursal La Piedad, Banco Nacional de México. Fotografía de Gladys Lizama Silva.

Todos los registros documentales contenidos en este volumen fueron tomados en fotografía digital y capturados luego en una base de datos excell, donde concentré la prosopografía económica de los 98 sujetos de crédito investigados entre 1905 y $1907 .{ }^{3} \mathrm{La}$ información documental que proporciona cada registro es desigual, en muchos casos hay dos informes de cada sujeto, en otros sólo uno. Hay varios donde la información es abundante, en otros escueta. Todos los registros informan sobre: la fecha cuando se obtuvo la información, el nombre, edad, estado civil, lugar de residencia, número de propiedades urbanas y rurales, valor de éstas, la actividad que realiza la

${ }^{3} \mathrm{El}$ archivo digitalizado con las fotografías de los registros de cada sujeto investigado lo puedo compartir, basta con escribir al correo electrónico mencionado al comienzo de la introducción a este documento. 
persona mencionada, capital neto o líquido estimado, pero además, proporciona lo que he llamado condición moral de los sujetos de crédito, esta información es de una riqueza extraordinaria para comprender cómo operaba una institución bancaria a fin de tener una representación lo más exacta posible de quiénes eran los sujetos de crédito. ${ }^{4}$

La única base de sustentación de la información proporcionada es la creencia en la buena fe de lo afirmado por el sujeto de crédito y el conocimiento que la sociedad tenía sobre éste a partir de la consulta por medio de informantes buscados por la institución. A manera de hipótesis puedo plantear que todo indica que la Sucursal del Banco Nacional de México de La Piedad aceptó la investigación como una base sólida para empezar a otorgar crédito.

\section{La Piedad a comienzos del Siglo XX}

Para contextualizar el documento creo necesario hacer un esbozo aunque sea somero de La Piedad entre 1905 y 1907. A comienzos de siglo, esta ciudad y las áreas circundantes comprendían el distrito $\mathrm{La}$ Piedad, se situaban igual que hoy al norte de Michoacán, limitaban al oeste con Jalisco y en el este con Guanajuato; la ciudad de La Piedad era la capital del distrito compuesto por los siguientes municipios: Yurécuaro, Tanhuato, Ecuandureo, Churintzio, Zináparo, Penjamillo y Numarán. ${ }^{5}$ En 1910, tenía 75,790 habitantes y La Piedad 10,604, o sea, el distrito concentraba apenas $7.6 \%$ de la población total de Michoacán (991,880 habitantes), y ocupaba el quinto lugar en el estado después de Morelia, Zamora, Uruapan y Puruándiro. ${ }^{6}$

${ }^{4}$ Hoy si acudimos a cualquier banco para solicitar un crédito hipotecario, llenamos largos formularios donde entregamos datos fidedignos de nuestra solvencia económica que el banco verifica digitalmente y consulta al Buró de Crédito el historial crediticio. A comienzos del siglo xx nada de eso existía, de tal manera que, podríamos preguntarnos cómo se enteraba el Banco Nacional de México de la calidad, honradez, solvencia y capacidad económicas del posible sujeto de crédito que recurría a pedir un préstamo.

${ }^{5}$ Ley de división territorial del estado de Michoacán de Ocampo, 1910, Morelia, Talleres de la Escuela Industrial Militar, "Porfirio Díaz", 1910.

${ }^{6}$ Secretaría de Fomento, Colonización e Industria, Dirección de Estadística, División territorial de los Estados Unidos Mexicanos correspondiente al Censo de 1910, Estado de 


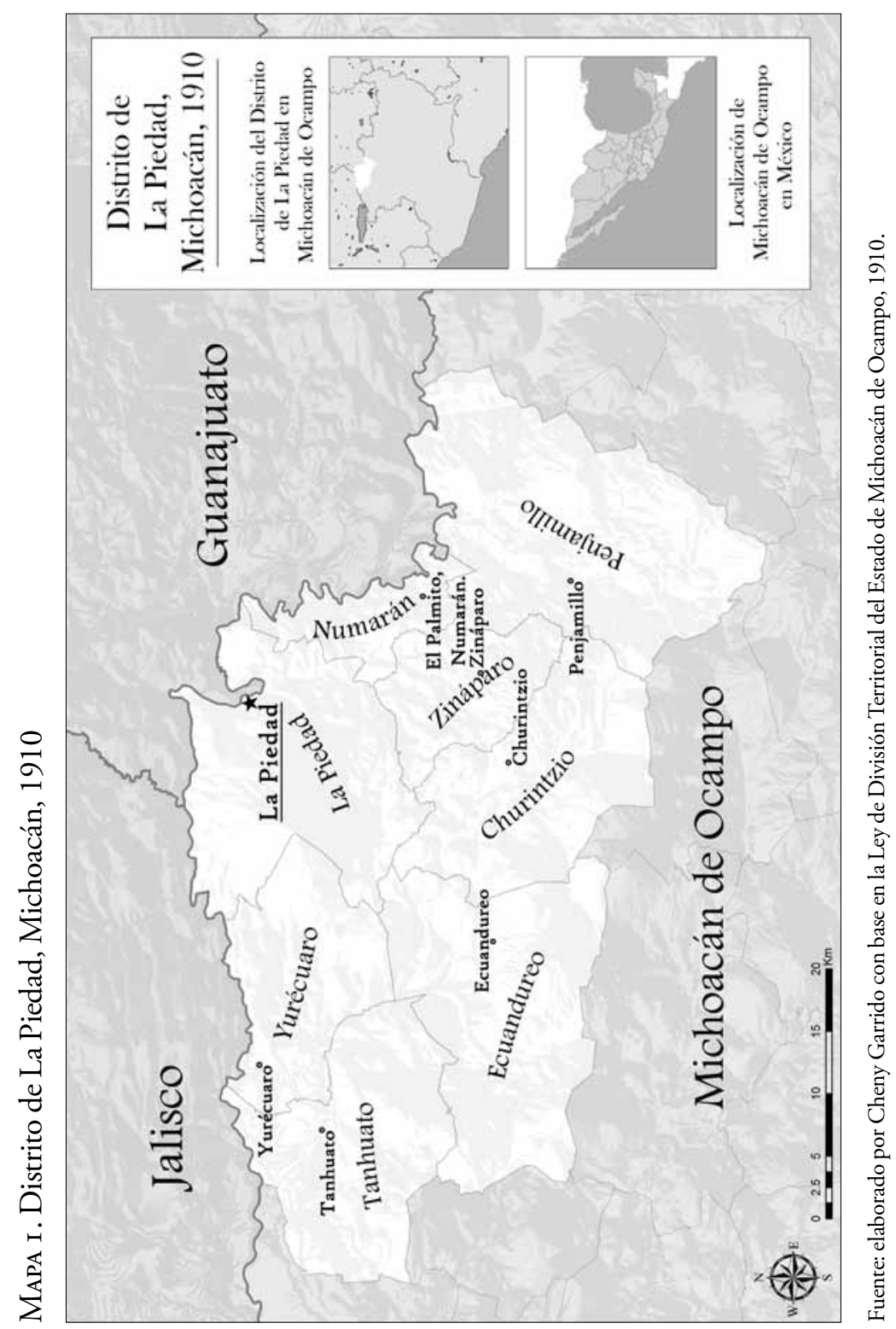


Según la escasa bibliografía, ${ }^{7}$ La Piedad era una ciudad más bien rural y agrícola que se benefició por ubicarse a orillas del río Lerma, pero también sufrió los perjuicios de las inundaciones. Desde la tercera década del siglo XIX, la construcción del famoso puente Cabadas agilizó la comunicación con Guanajuato pues hizo más expedito el comercio de arrieros en sus hatajos de mulas que venían de Zamora o de otros lugares de Michoacán. El comercio se intensificó a mayor escala cuando, en 1903, también por esta vía pasó la ruta del tranvía que partía desde la Casa del Diezmo, en el centro de La Piedad, hasta la estación del Ferrocarril Central, y, de allí, las mercancías partían hacia el norte o el centro del país. Hacía 1904 ya disponía de algunas líneas telefónicas, y para 1906 La Piedad empezó a contar con alumbrado eléctrico en sus calles.

Como dije líneas arriba, La Piedad era un espacio territorial principalmente agrícola, productor de maíz, garbanzo, frijol, trigo, camote y chile; aún no era una zona principalmente ganadera, sin embargo, disponía de una importante producción de ganado vacuno, lanar, cabrío y porcino; además, desde 1909, comenzó a proporcionar el servicio de degüello en la casa de abasto. Como toda ciudad de transito también desarrolló una importante actividad mercantil al mayoreo y menudeo de granos, abarrotes, cajones de ropa, etcétera. Hubo también algunas fábricas de jabón, cigarros y gaseosas. Hay un relativo consenso en afirmar que la ciudad de La Piedad estuvo económicamente más vinculada a Guanajuato que a Michoacán.

Como era de esperar, el crecimiento de las actividades productivas y mercantiles de la época porfiriana piedadense redundó de igual manera en el auge de la actividad financiera, así fue como poco a poco se crearon las sucursales bancarias: en 1898, nació la agencia del Banco de Londres y México y en 1905 se fundó la Sucursal del Banco Nacional de México, cuyo primer gerente fue Juan Salvador Fontanilla.

Michoacán, México, Departamento de Talleres Gráficos de la Secretaría de Fomento, Colonización e Industria, 1917, 7.

${ }^{7}$ Véase Sergio García Ávila, "La Piedad: desarrollo urbano al margen del río Lerma, 1890-1910", en Pueblos, villas y ciudades de Michoacán en el porfiriato, Gerardo Sánchez Díaz et al., Morelia, Universidad Michoacana de San Nicolás de Hidalgo, 1991, 73-86. 
Con base en el Libro de Informes -98 probables sujetos de crédito-y en la cifra total de población del distrito La Piedad, se deduce que sólo $0.1 \%$ pudo hipotéticamente tener acceso al crédito de la Sucursal del Banco Nacional de la localidad.

\section{DistRIBUCIÓN REgIONAL DE LOS SUJETOS DE CRÉDITO}

Como se puede observar a través del cuadro 1 , gráfica 1 y el mapa 2, correspondientes a la Sucursal La Piedad del Banco Nacional. Ésta

Cuadro i. Distribución regional de los sujetos de crédito de la Sucursal del Banco Nacional de México en La Piedad, 1905-1907

\begin{tabular}{lcc}
\hline \multicolumn{3}{c}{ Clientes investigados } \\
\hline Municipio & Número de casos & Porcentaje \% \\
\hline Ayo el Chico & 1 & 1.02 \\
Buena Vista & 1 & 1.02 \\
Churintzio & 5 & 5.10 \\
Ecuandureo & 6 & 6.12 \\
El Palmito, Numarán. & 1 & 1.02 \\
La Piedad & 58 & 59.18 \\
Pajacuarán & 4 & 4.08 \\
Penjamillo & 5 & 5.10 \\
San José Corralitos & 1 & 1.02 \\
Tanhuato & 3 & 3.06 \\
Tingüindín & 6 & 6.12 \\
Tirimácuaro & 1 & 1.02 \\
Yurécuaro & 5 & 5.10 \\
Zináparo & 1 & 1.02 \\
TOTAL & 98 & $100 \%$ \\
\hline
\end{tabular}

Fuente: Elaboración propia con base en Libro de Informes de la Sucursal del Banco Nacional de México de La Piedad, 1905-1907. 
Gráfica I. Ubicación geográfica de los sujetos de crédito de La Piedad, 1905-1907

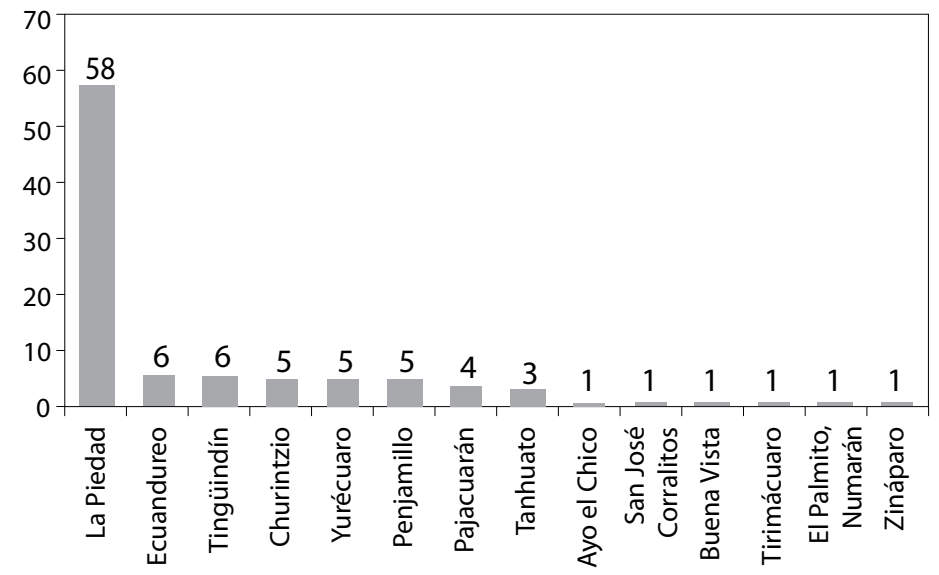

Fuente: Elaboración propia con base en Libro de Informes de la Sucursal del Banco Nacional de México de La Piedad, 1905-1907.

atendió una extensa región que tuvo como centro dicha ciudad, sin embargo, el mayor porcentaje, 59.18 de los sujetos de crédito investigados residía, como era de esperar, en La Piedad; allí se concentraban los mayores capitales, un número considerable de comerciantes y los hacendados más ricos. La diferencia con el resto de los espacios territoriales es muy elocuente.

\section{Centralización del CAPital}

El corte histórico 1905-1907, muestra una constante estructural, a saber, la fuerte centralización del capital y la desigual repartición del mismo entre los más ricos y los sectores medios. De los 98 sujetos de crédito, sólo 73 manifestaron explícitamente el capital estimado del cual disponían y, de ese total, diecisiete concentraban $65.94 \%$ del capital declarado. La diferencia con el resto de los individuos con capital, como puede observarse en el cuadro 2, es abismal. 


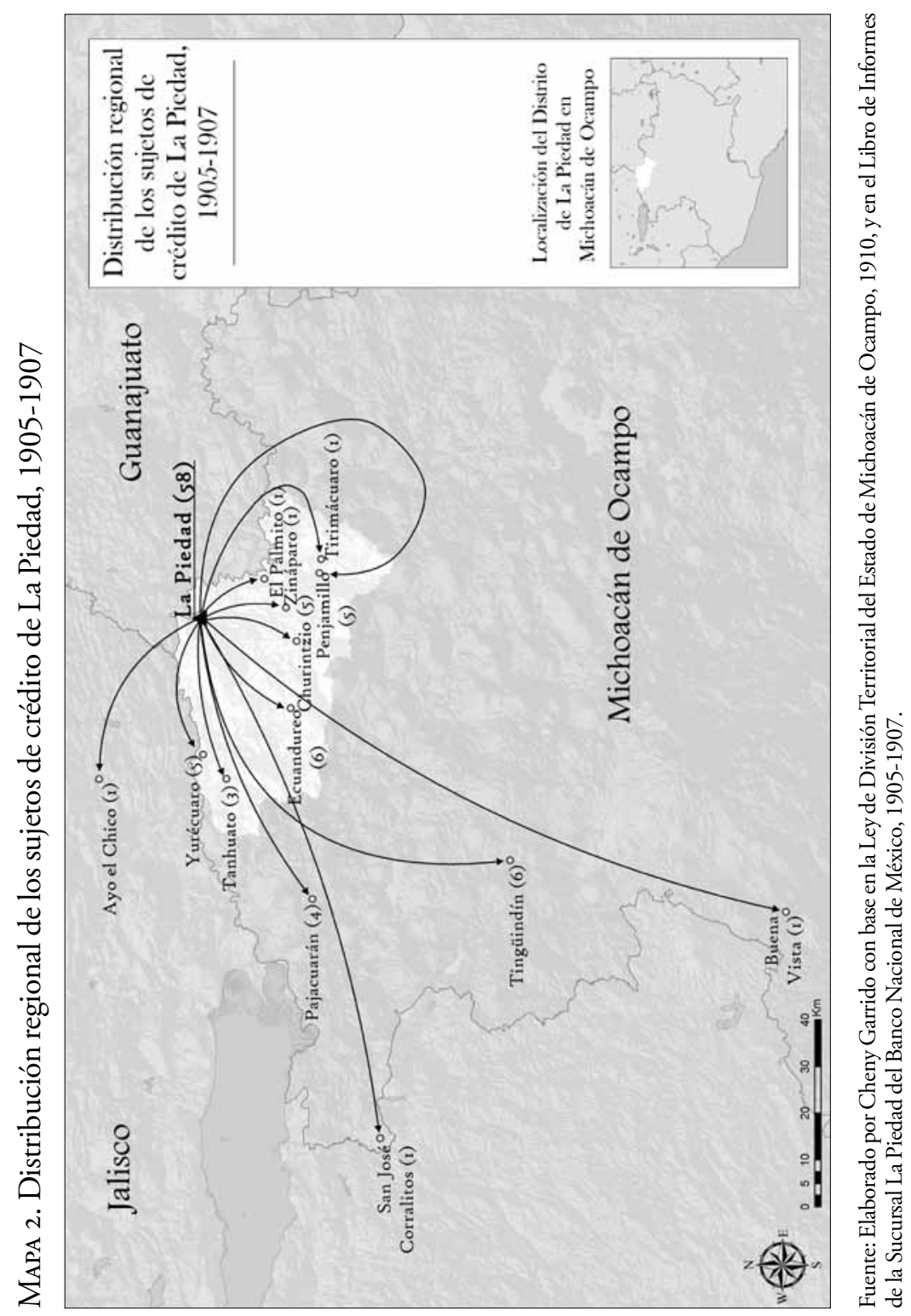


Cuadro 2. Centralización del capital en el Distrito de La Piedad y aledańos de 1905-1907

\begin{tabular}{lcrrr}
\hline Capitales individuales & $\begin{array}{c}\text { Número } \\
\text { de casos }\end{array}$ & $\%$ & Total & $\%$ \\
\hline Más de 100,000 & 17 & 23.28 & $3,195,000$ & 65.94 \\
De 50,000 a 99,000 & 12 & 16.43 & 725,000 & 14.96 \\
De 20,000 a 49,000 & 27 & 36.98 & 755,000 & 15.58 \\
De 10,000 a 19,000 & 13 & 17.80 & 145,000 & 2.99 \\
De 0 a 9,999 & 4 & 5.47 & 25,000 & 0.51 \\
TOTAL & 73 & 100 & $4,845,000$ & 100 \\
\hline
\end{tabular}

Fuente: Elaboración propia con base en Libro de Informes de la Sucursal del Banco Nacional de México de La Piedad, 1905-1907.

\section{ACTIVIDAdES Y OCUPACIONES ECONÓMICAS DE LOS SUJETOS DE CRÉDITO}

Sin lugar a dudas, La Piedad, fue el espacio donde el capital invertido se concentró en la explotación de la tierra, sin embargo, la mayor parte de los clientes investigados tenía su capital diversificado como suele ser la tónica regional (Lizama Silva 2009 y 2013). Con base en la información documental proporcionada por el Libro de Informes I, encontré que de los 98 individuos o colectivos investigados sólo 86 expresaron su profesión, ocupación u oficio, y doce los omitieron. No obstante, al llevar a la práctica el examen, hice arbitrariamente agrupaciones con base en el tipo de ocupación, pero también tomando en consideración los tipos de propiedades y si combinaban más de una actividad económica. La clasificación resultante construida puede observarse en el cuadro 3 y la gráfica 2 .

Tanto el cuadro 3 como la gráfica 2 evidencian el carácter agrícola del distrito, no obstante, los agricultores combinaron casi siempre las labores agrícolas con la crianza de ganado, el comercio y el préstamo a interés. Los que afirmaron ser empresarios eran: uno fabricante de rebozos y otro de cigarros. Los que se declararon sólo como 
Cuadro 3. Actividades y ocupaciones económicas de los sujetos de crédito Sucursal La Piedad, Banco Nacional de México 1905-1907

\begin{tabular}{lr}
\hline Agricultor & 56 \\
Agricultor/comerciante & 7 \\
Agricultor/prestamista & 1 \\
Comerciante & 13 \\
Carpintero & 1 \\
Prestamista & 1 \\
Banquero & 1 \\
Empresario & 2 \\
Sacerdote & 3 \\
Médico & 1 \\
Sin ocupación & 12 \\
\hline
\end{tabular}

Fuente: Elaboración propia con base en Libro de Informes de la Sucursal del Banco Nacional de México de La Piedad, 1905-1907.

comerciantes eran casi todos propietarios de tiendas mixtas o de abarrotes o de ambos rubros.

Sorprenderá al lector que entre los sujetos de crédito investigados hubo tres sacerdotes: José R. Ávalos, residente en La Piedad, propietario de una quinta, una huerta y varias casas y su capital se estimó en \$100,000. El segundo, Luis Orozco y Jiménez, residente en Churintzio, pero originario de Zamora, era el hermano mayor de Francisco, obispo de Chiapas, entre 1902 y 1912, y arzobispo de Guadalajara de 1913 a $1936,{ }^{8}$ y según la información documental, Luis era propietario de una fracción de hacienda, una huerta y una casa y su capital se estimó en $\$ 100,000$. El tercero llevó por nombre Reynaldo Villaseñor, él manifestó tener varias propiedades y disponer de un capital estimado de $\$ 50,000$. Además se encontraron un profesionista, un artesano, un prestamista y un "banquero" al decir del Libro de Informes I.

${ }^{8}$ Julia Preciado, "Dos imágenes del Arzobispo de Guadalajara Francisco Orozco y Jiménez” en Desacatos, núm. 40, México, Ciesas, 2012, 80. 
Gráfica 2. Ocupaciones económicas de los sujetos de crédito de La Piedad, 1905-1907

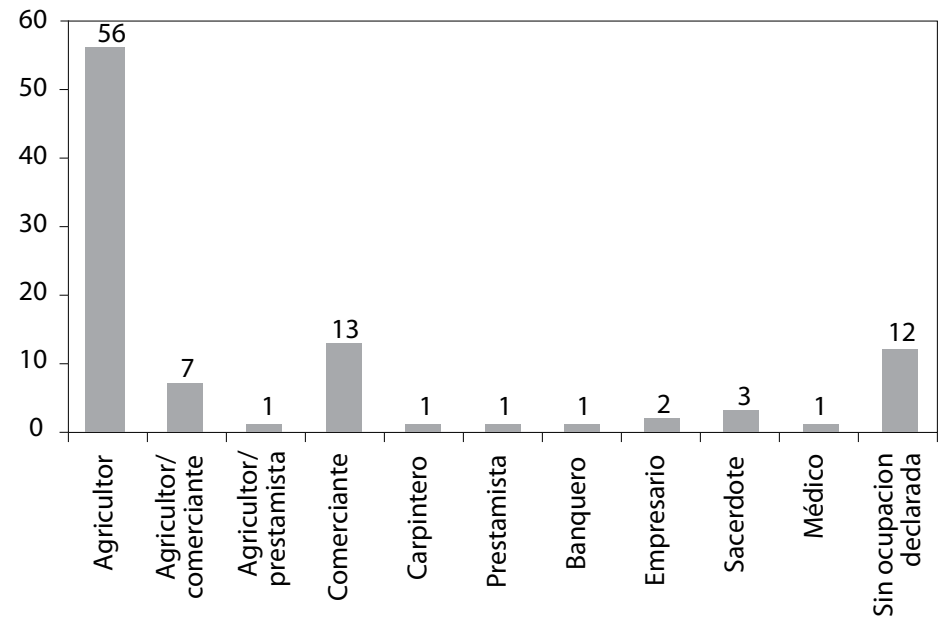

Fuente: Elaboración propia con base en Libro de Informes de la Sucursal del Banco Nacional de México de La Piedad, 1905-1907, y el cuadro 3.

\section{GÉNERo de los SUJeTOS DE CRÉdito}

El atributo de género también es posible detectarlo en los registros del Libro de Informes i de la Sucursal La Piedad del Banco Nacional de México. En mi opinión es importante resaltar que los posibles sujetos de crédito no sólo fueron hombres, muy por el contrario, hubo once mujeres que fueron sujetos de crédito investigadas que representan $11 \%$ del total. Suma nada despreciable, si se piensa que vivieron a comienzos del siglo xx, momento en que ellas no tenían mucho acceso al mundo del crédito. En su mayoría eran viudas que una vez fallecido el marido tomaban las riendas de los negocios, fue el caso de dońa Josefa Falconi viuda de Chavolla, que junto a sus hijos eran los hacendados más ricos de La Piedad, y no sólo fueron clientes de la Sucursal de La Piedad, sino también de la de Zamora. ${ }^{9}$

${ }^{9}$ Gladys Lizama Silva, "De buena moralidad y costumbres a tracaleros de mala fe. Calificación crediticia de la Sucursal Zamora, Michoacán, del Banco Nacional de México 1905-1907", artículo entregado a publicación y en dictamen. 
Cuadro 4. Género de los sujetos de crédito, Sucursal del Banco Nacional de México, La Piedad, 1905-1907

Hombres 86

Mujeres 11

Fuente: Elaboración propia con base en Libro de Informes de la Sucursal del Banco Nacional de México de La Piedad, 1905-1907.

\section{Calificación CRediticia de los Sujetos de CRÉdito}

Quizás el dato determinado más ajeno al sujeto investigado sea cómo el banco lo clasificó - una vez que éste recibió la información o después que fue entrevistado-, en su calidad de sujeto de crédito. En este ámbito fue donde influyó no sólo el capital estimado por el banco o el valor de las propiedades del individuo o grupo familiar, sino también lo que he llamado la condición moral que se le adjudica en la investigación y que quedó plasmada en cada registro. Esta última refiere la buena o mala reputación en los negocios, la honorabilidad y buenas costumbres, la puntualidad en los compromisos adquiridos, la solvencia, la inmoralidad y deshonestidad, las malas costumbres como la embriaguez y la práctica del juego.

En el cuadro 5 y la gráfica 3 cuantifico los buenos, aceptables, aceptables con garantía, regulares e inaceptables sujetos de crédito. Aclaro que el Libro de Informes I no define ninguno de estos conceptos, sólo los aplica; se entiende que hay una jerarquización, no obstante, queda ambigua la diferencia que hubo, por ejemplo, entre un sujeto aceptable y otro regular. Para clarificar debí recurrir a lo que cada registro documental sostiene sobre el monto del capital y la condición moral de cada uno; ahora bien, hay que dejar en claro que la calificación crediticia asignada a cada sujeto no es lo que he denominado condición moral del mismo.

Agrego que la calificación crediticia "buen" sujeto de crédito estuvo directamente vinculada siempre al monto de capital disponible, al número de propiedades, pero, sobre todo, a la buena reputación con la cual se le tildaba. 
Cuadro 5. Calificación crediticia de los sujetos de crédito, Sucursal del Banco Nacional de México, La Piedad, 1905-1907

\begin{tabular}{lccccc}
\hline Buenos & Aceptables & $\begin{array}{c}\text { Aceptables } \\
\text { con garantia }\end{array}$ & Regulares & $\begin{array}{c}\text { Inacep- } \\
\text { tables }\end{array}$ & $\begin{array}{c}\text { Sin espe- } \\
\text { cificar }\end{array}$ \\
\hline 2 & 56 & 6 & 24 & 5 & 5 \\
\hline
\end{tabular}

Fuente: Elaboración propia con base en Libro de Informes de la Sucursal del Banco Nacional de México de La Piedad, 1905-1907.

Gráfica 3. Calificación crediticia de los sujetos de crédito de La Piedad, 1905-1907

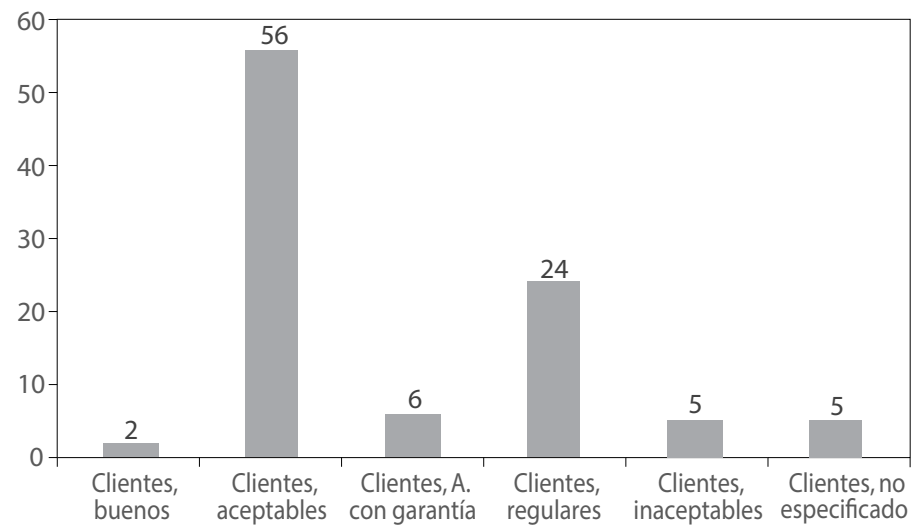

Fuente: Elaboración propia con base en Libro de Informes de la Sucursal del Banco Nacional de México de La Piedad, 1905-1907.

BibLIOGRAFÍA

Archivo del Banco Nacional de México

Cerutti, M. y Marichal, C., La banca regional en México, 18701930, México, El Colegio de México, Fondo de Cultura Económica, 2003.

Comisión Nacional Bancaria y de Seguros (México), Historia 
de la banca mexicana, México, Comisión Nacional Bancaria y de Seguros, 1984.

Del Angel, G., La banca mexicana: reconstrucción y análisis de estadísticas históricas, 1940-1982, México, Centro de Investigación y Docencia Económicas, 2002.

Del Ángel, G. y Marichal, C., Historiografia reciente de la banca en México: siglos XIX y XX, México, Centro de Investigación y Docencia Económicas, 2002.

Lagunillas, A., Historia de la banca y moneda en México, México, Jus, 1981.

Lizama Silva, G., "Los capitales zamoranos a principios del siglo xx", en Historia Mexicana, núm. 4, vol. xxxix, México, El Colegio de México, 1990, 1032-1042.

, Zamora en el porfiriato. Familias, fortunas y economía, $1^{\text {a }}$ reimpresión, Zamora, El Colegio de Michoacán, Ayuntamiento de Zamora, 2009.

Ludlow, L. y Marichal, C., eds., Banca y poder en México (18001925), México, Grijalbo, 1986.

Ludlow, L. y Marichal, C., La banca en México, México, El Colegio de México, 1998.

Manero, A., La revolución bancaria en México: una contribución a la historia de las instituciones de crédito en México, México, Talleres Gráficos de la Nación.

Memoria sobre los diversos ramos de la Administración Pública del Estado de Michoacán, 1889, Morelia, Litografía de Artes, 1957.

Peñafiel, A., Censo y División territorial del estado de Michoacán verificado en 1900, México, Dirección General de Estadísticas, Imprenta y fototipia de la Secretaría de Fomento, 1905.

Preciado Zamora, J., "Dos imágenes del Arzobispo de Guadalajara Francisco Orozco y Jiménez", en Desacatos, núm. 40, México, Ciesas, 2012, 79-96.

Turrent, E., "Historia sintética de la banca en México", Banco de México, 2007, www.banxico.org.mx/.../\%7BFFF17467-8ED62AB2-1B3B-ACCE5C2A 


\section{Documento}

Libro de informes i, Sucursal La piedad, Banco NaCional de MÉXico I905-I 907

Como dije líneas atrás, la institución encargó la investigación estableciendo una serie de preguntas que debían contestar los informantes y los propios sujetos investigados. Es importante recalcar, que desde los orígenes, las instituciones bancarias, en este caso, el Banco Nacional de México, hicieron investigaciones de esta naturaleza para tener un conocimiento más cercano de los individuos que acudieron a solicitar crédito. Es significativo recalcar que hasta el día de hoy, este tipo de investigaciones continúa realizándose, naturalmente con técnicas y metodologías especializadas, conocidas por su nombre en inglés credit scoring.

A fin de entregar el documento ordenado se presenta en una base que contiene una serie de variables, a saber: fecha, nombre, residencia, edad, estado civil, ocupación, monto del capital, propiedades, valor de las propiedades, calificación crediticia, condición moral y observaciones generales. Estas dos últimas variables son cualitativas y permiten conocer la opinión que la institución bancaria tenía de cada individuo.

Con el objetivo de facilitar la lectura y la búsqueda en la base de datos, se ordenaron por órden alfabético los hombres y mujeres posibles sujetos de crédito. 


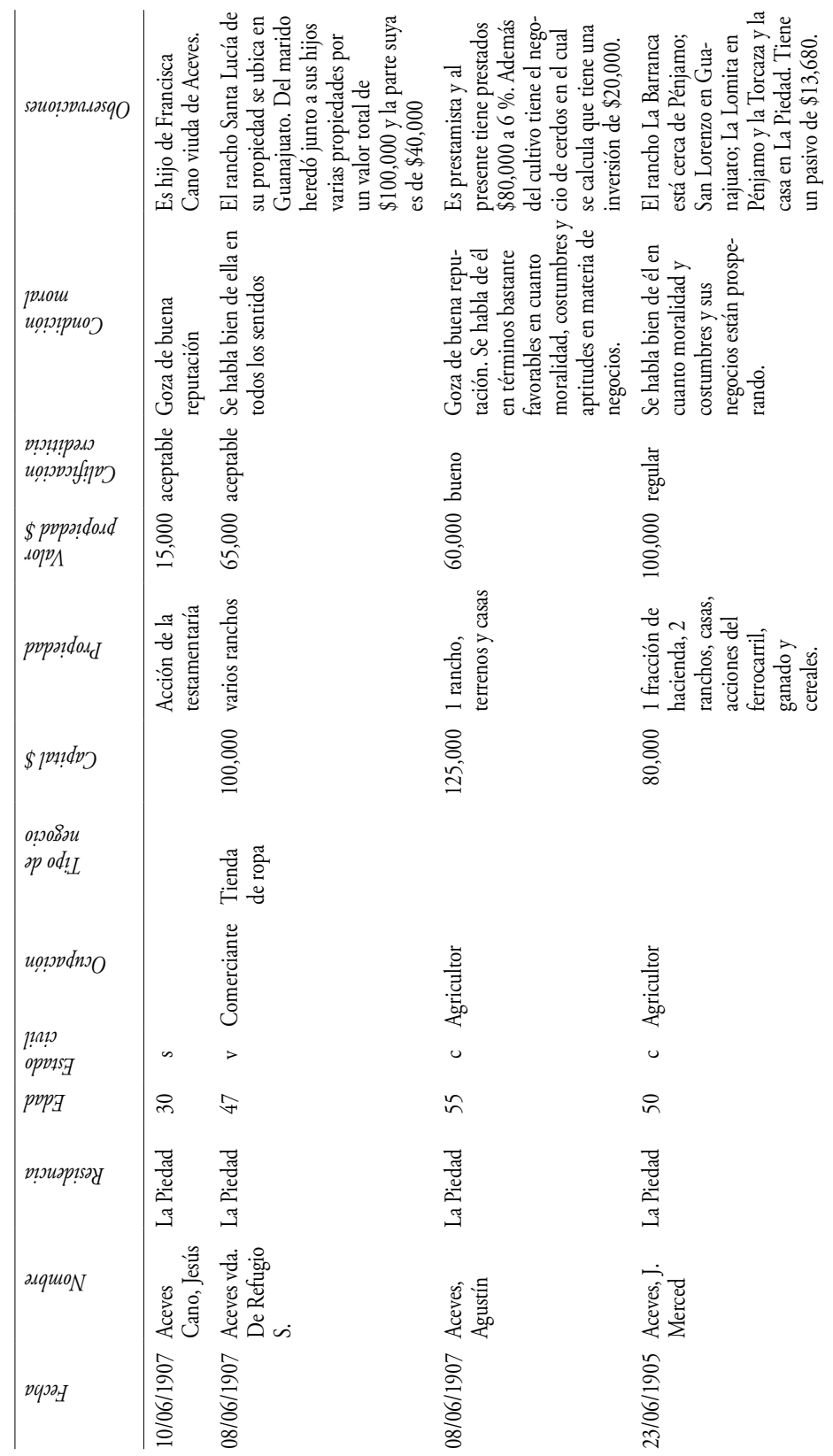




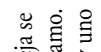

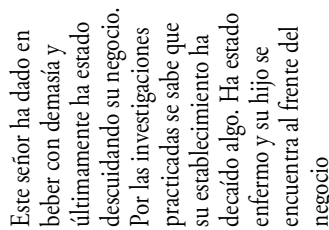

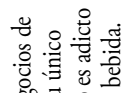

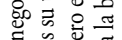

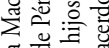

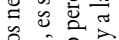

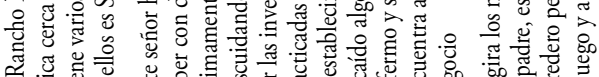

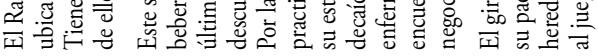

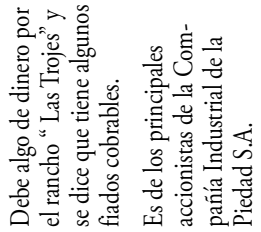

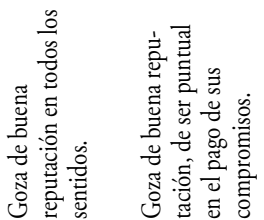

它离

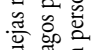

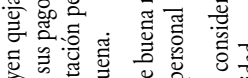

की

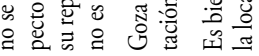

密诺

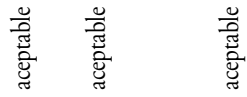

कृ

용

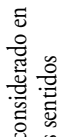

음

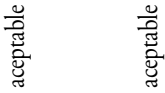

$\underset{\infty}{\circ}$

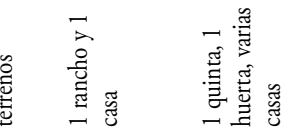

$\begin{array}{llll}8 & 8 & 8 & 8 \\ 0 & 0 & 0 & 0 \\ 0 & 0 & 0\end{array}$

蒂

苛

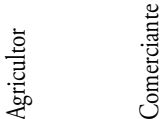

䒕

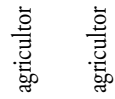

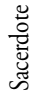

8

8

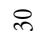

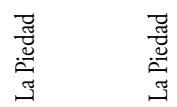

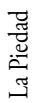

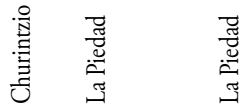

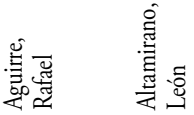

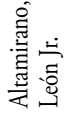

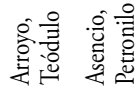

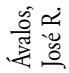

总 䓂

흥

㐔

命 


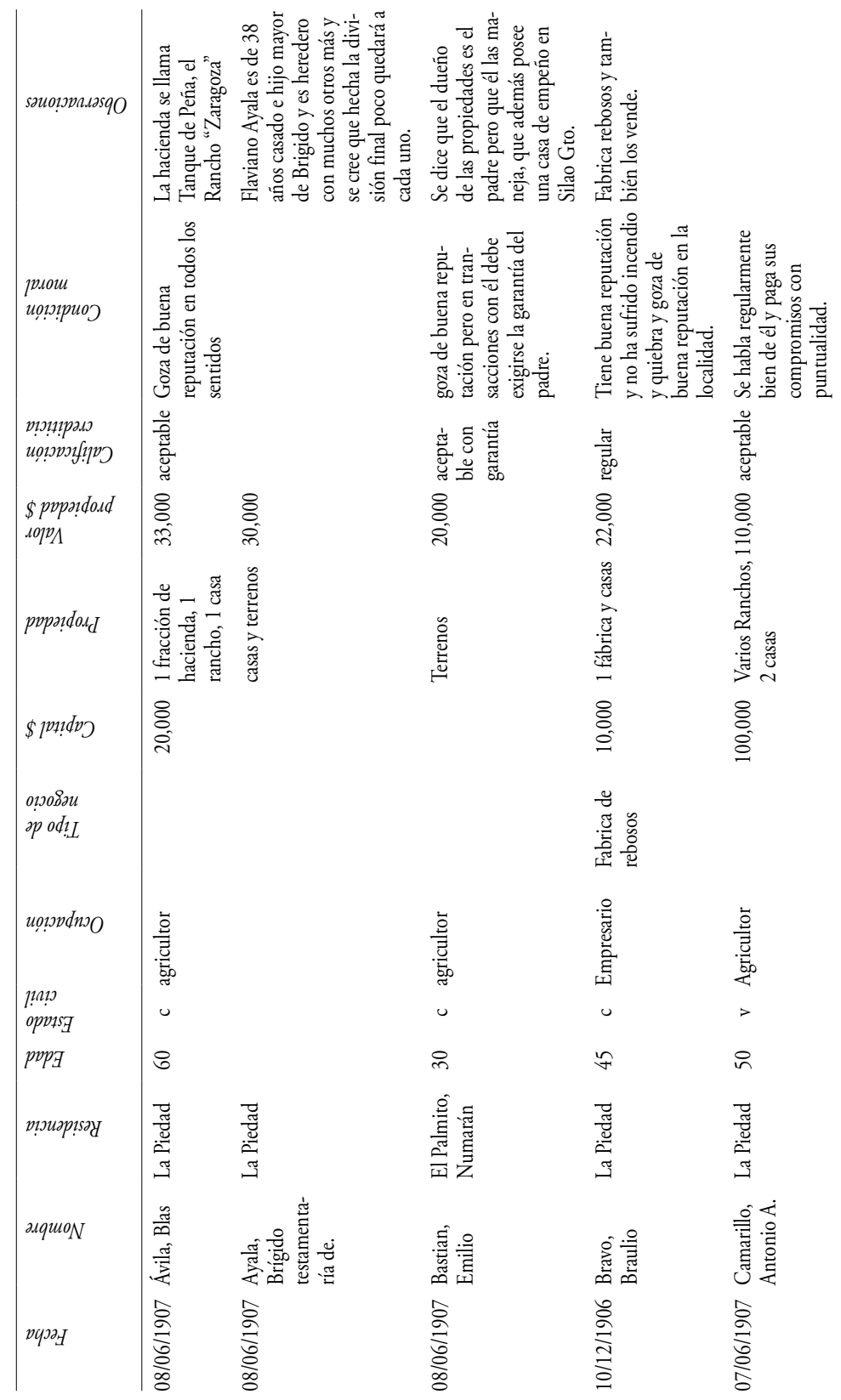



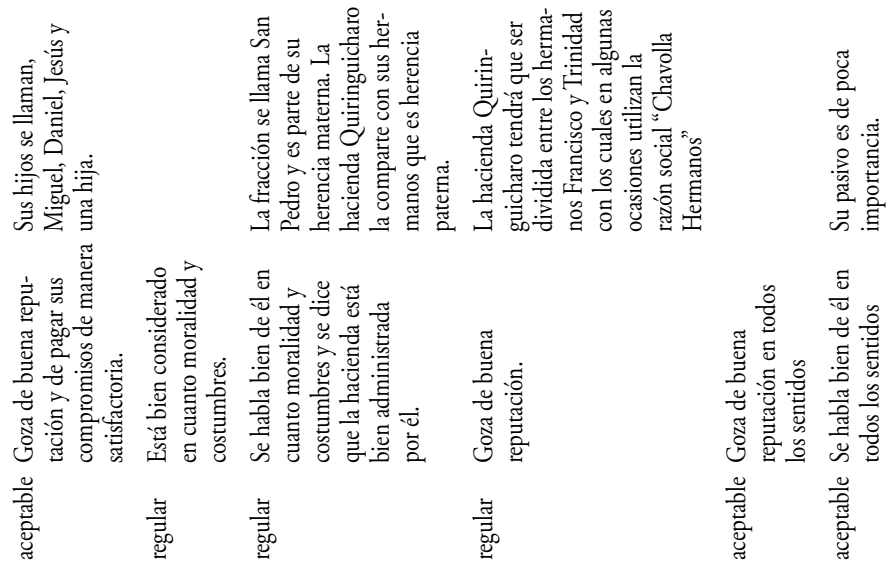

突

용

용

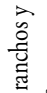

资

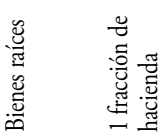

용

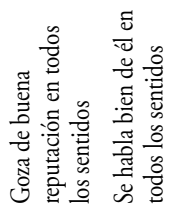

ᄋ్

$\begin{array}{ll}8 & 8 \\ 8 & 8 \\ 1 & 8\end{array}$

苞

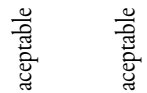

용

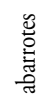
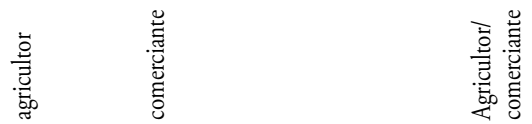

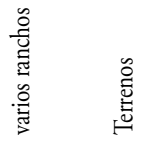

8
8
8
$\circ$

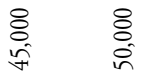

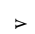

응

శ

๙

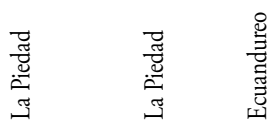

\&

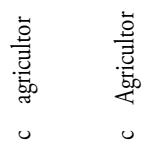

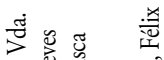

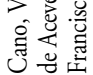

离

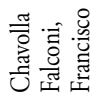

के

ڤ్

ڤે

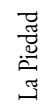

in $n$

莬芯

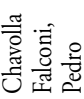

ま

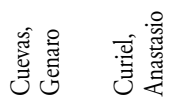

ڤे ڤे 


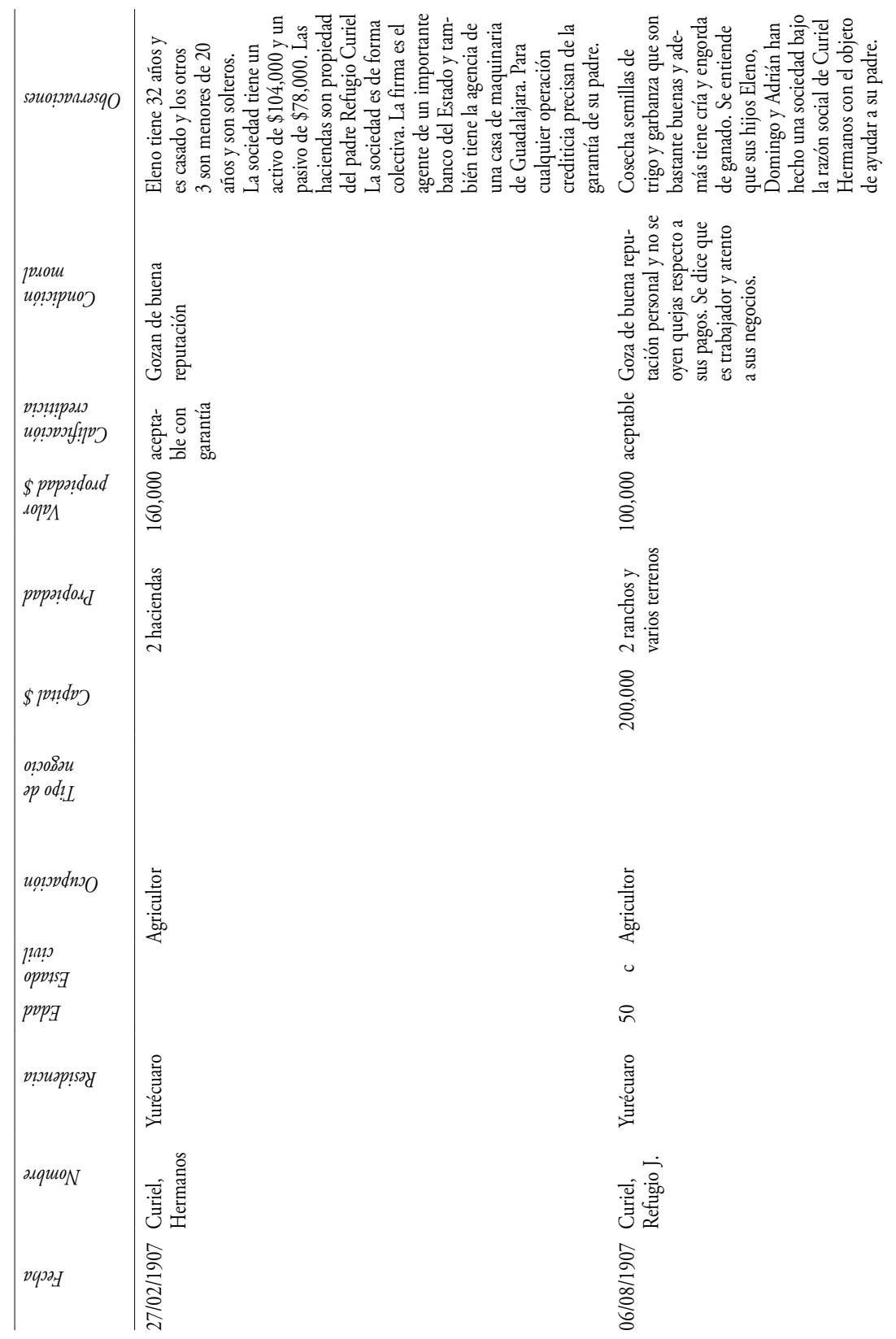



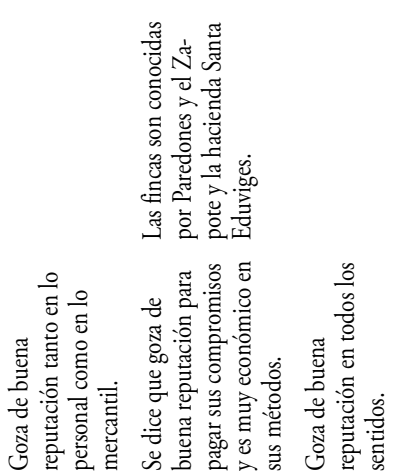

咅离

言

.

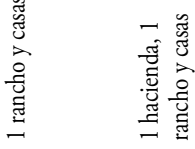

高

¿े

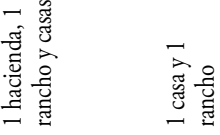

\&

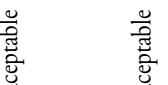

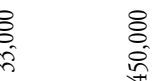

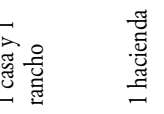

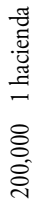

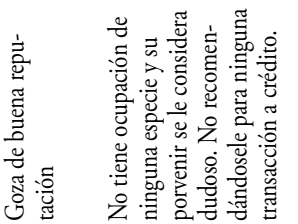

高

으 은

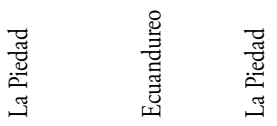

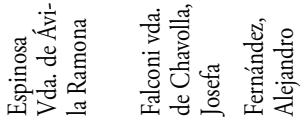

ڤे
它 $\frac{\dot{U}}{\Xi}$

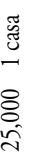

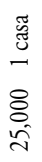

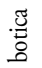

营

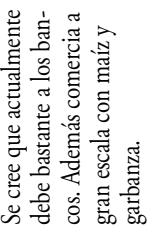

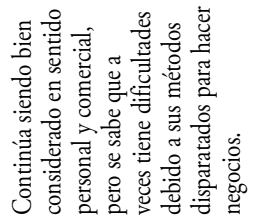

芼

$\stackrel{8}{0}$<smiles>C[13CH][13CH]</smiles>

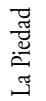

莺莺莺

高 


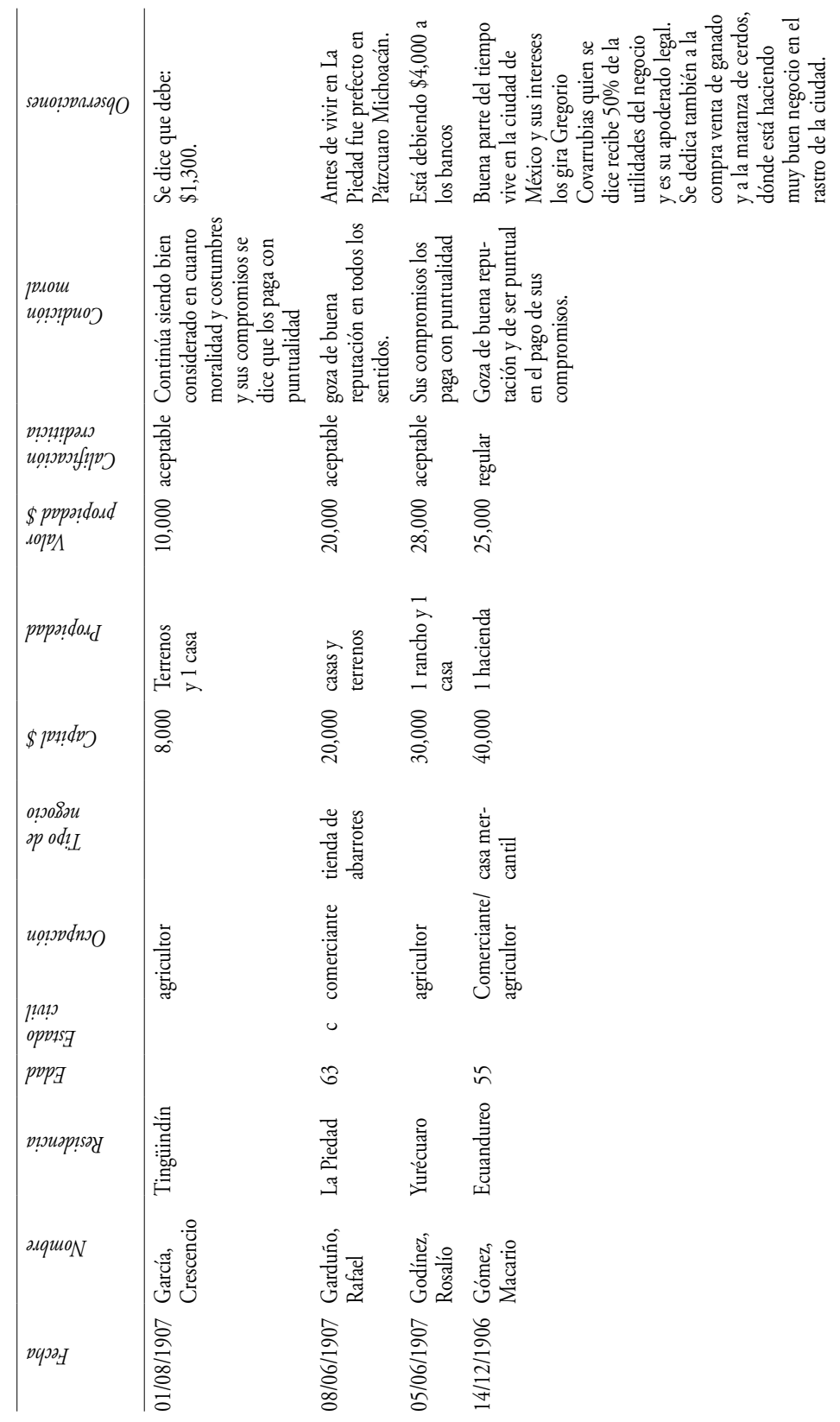




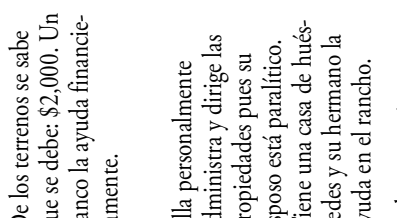

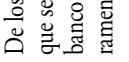
举委
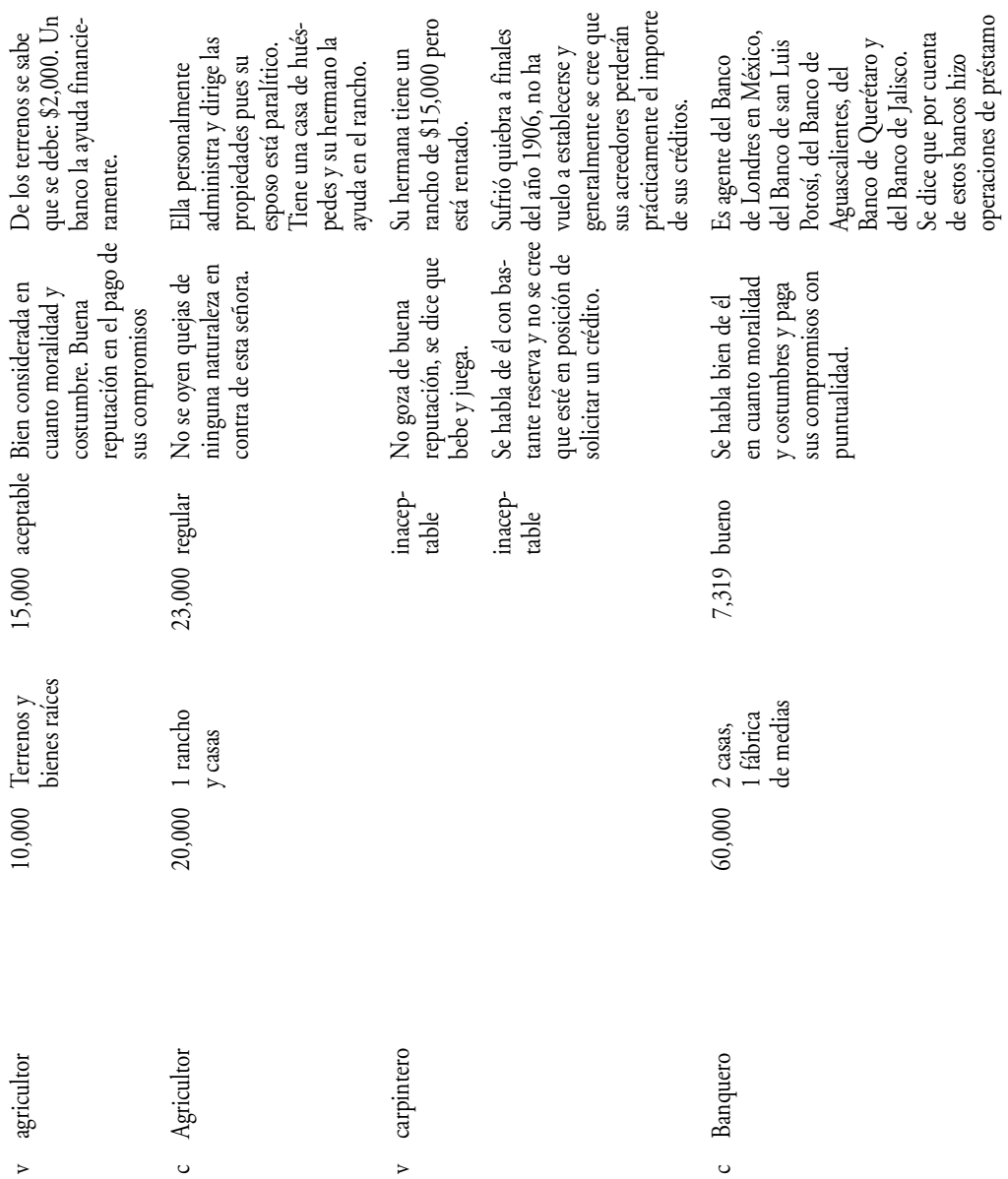

in $n$

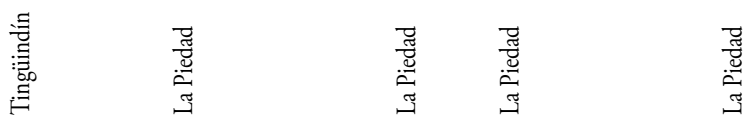

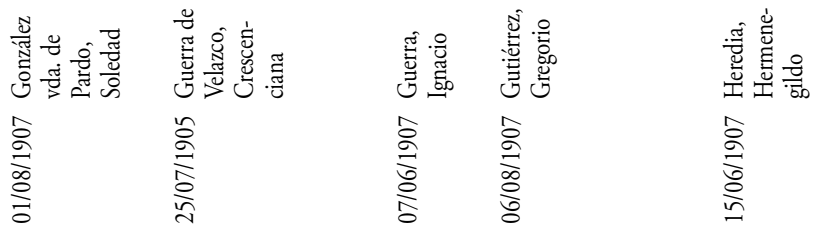




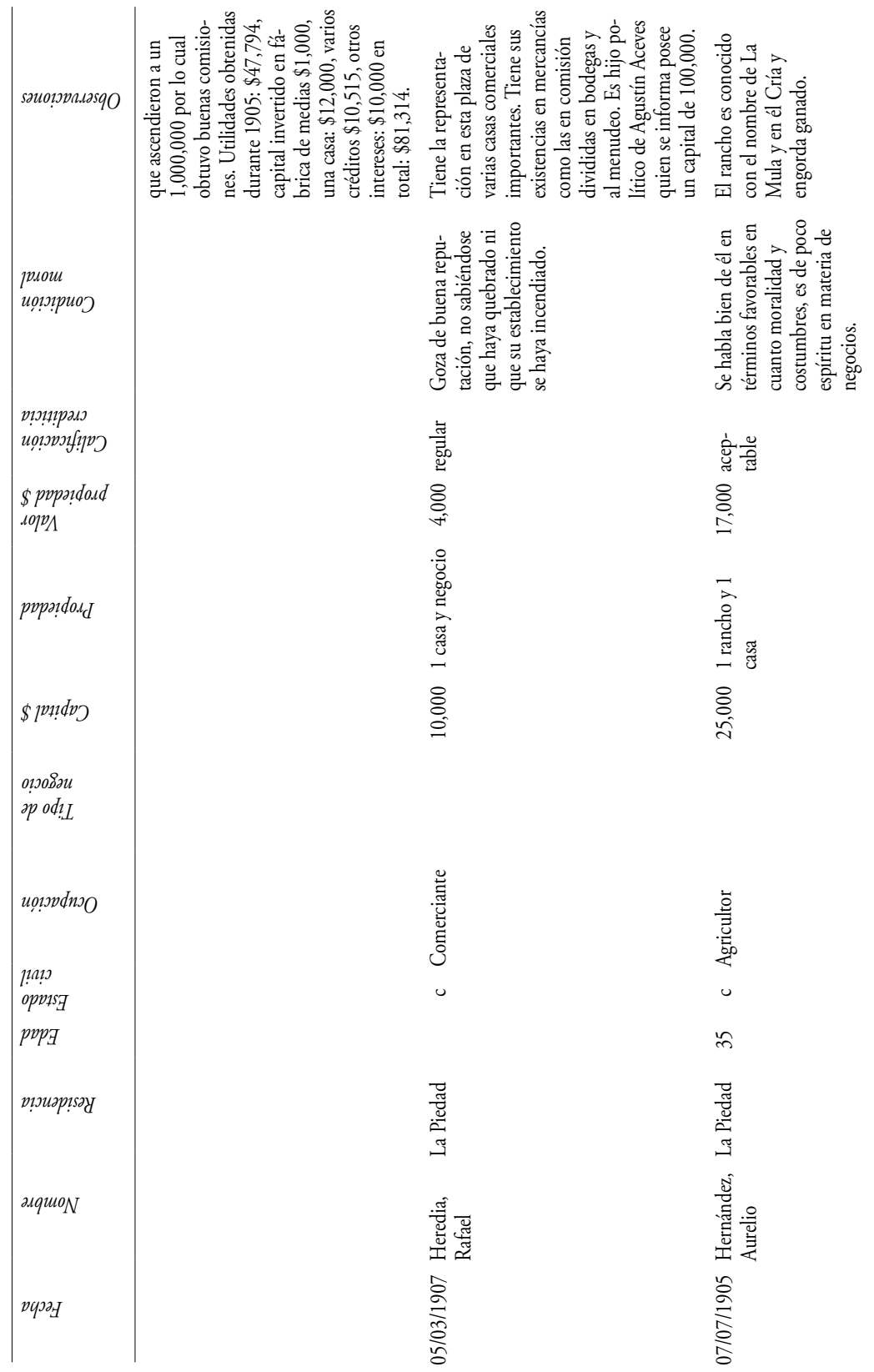



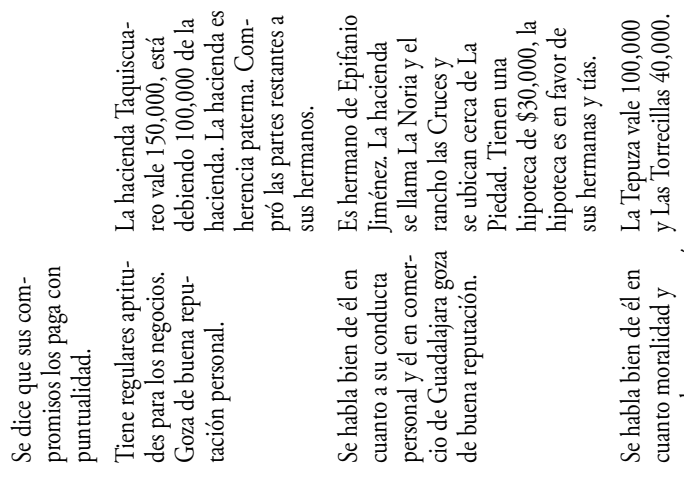

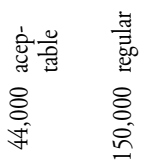

흃

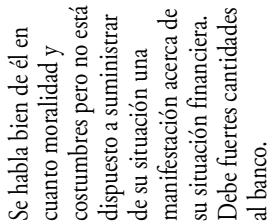

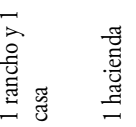

8
๙
ำ

홇

ᄋ్ㅇㅇㅇ

용

7

害

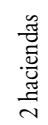

용 ถ

8̊ㅇㅇㅇㅇㅇ

8

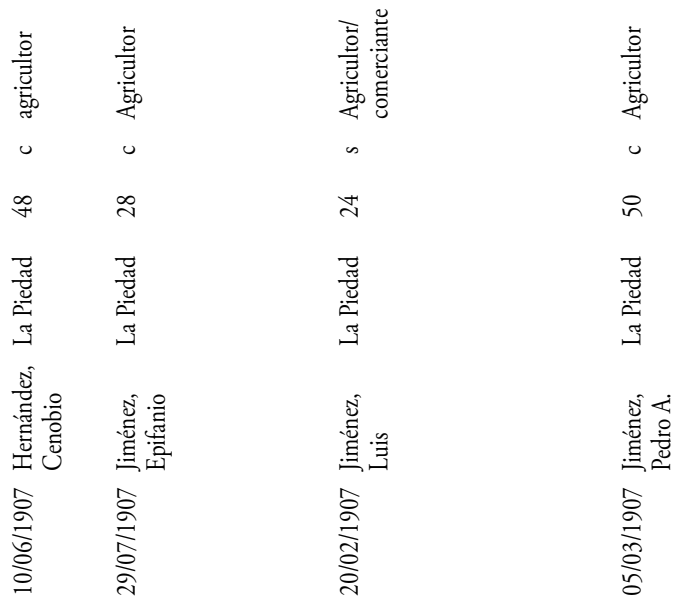




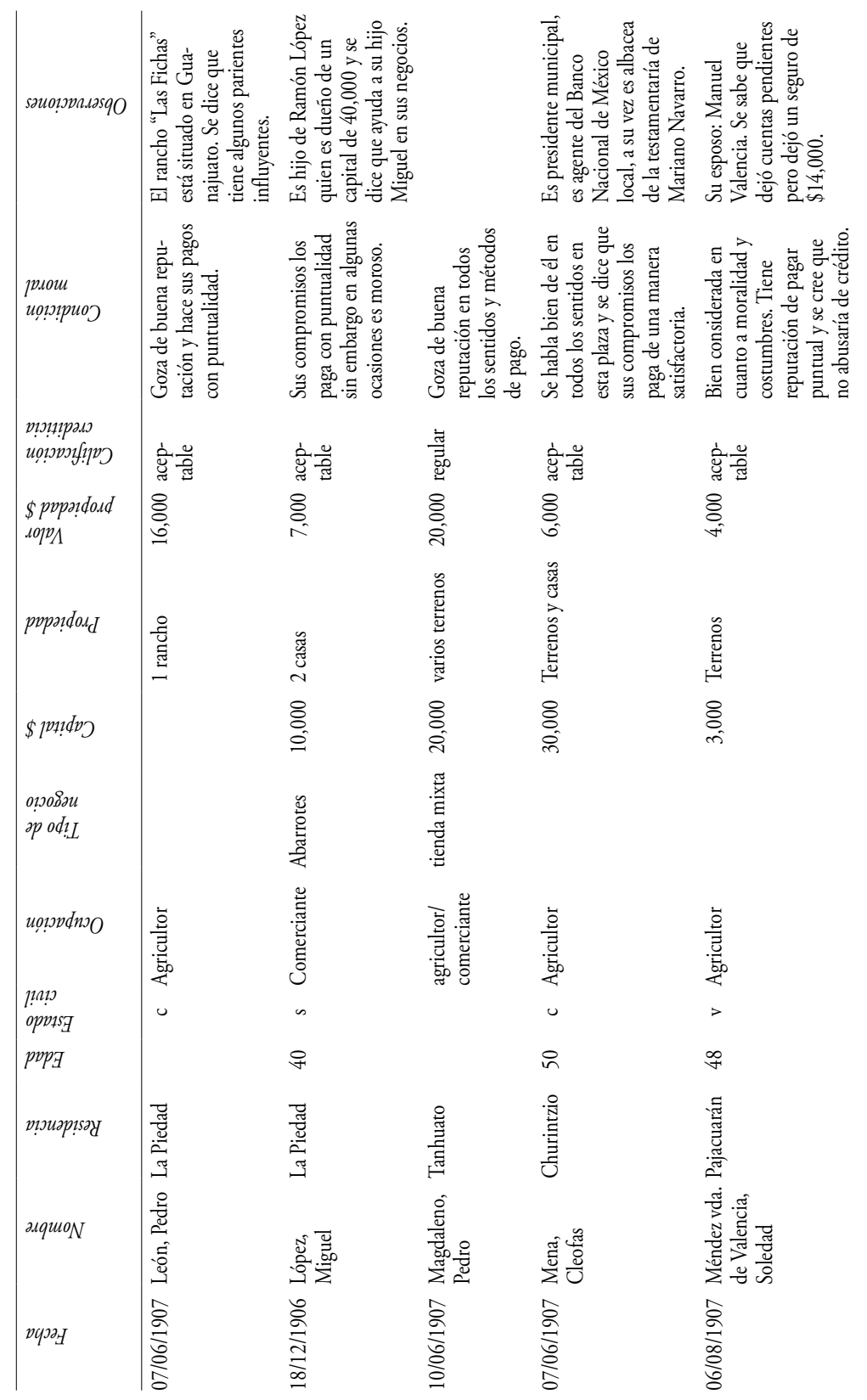



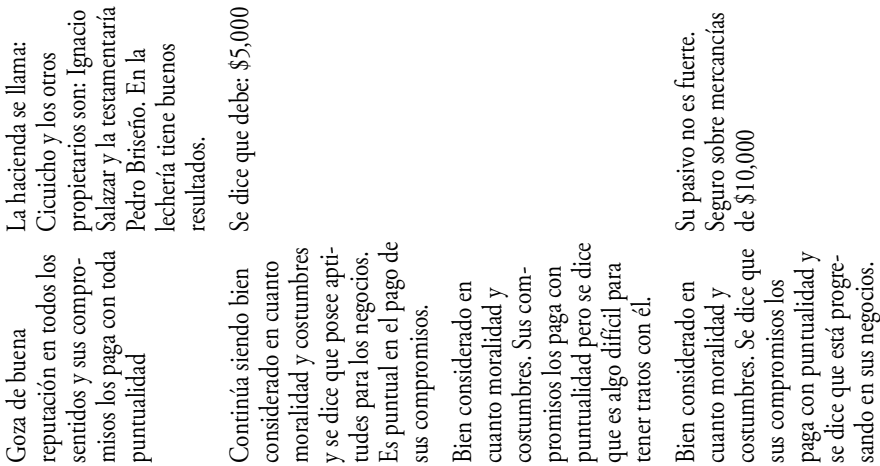

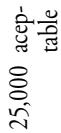

홇를

홇를

홓들

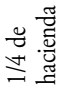

ᄋ్ఠ

ஓ

:

产

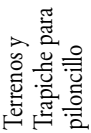

蓠

@

\&

@

छ̊

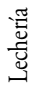

$\frac{\vec{s}}{\vec{z}}$
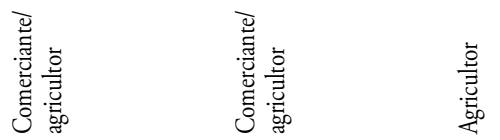

䔍

穿

กิ

우

竎。

离蒡

冚

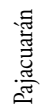

ลे

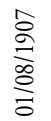

苞

产

高

ڤे 


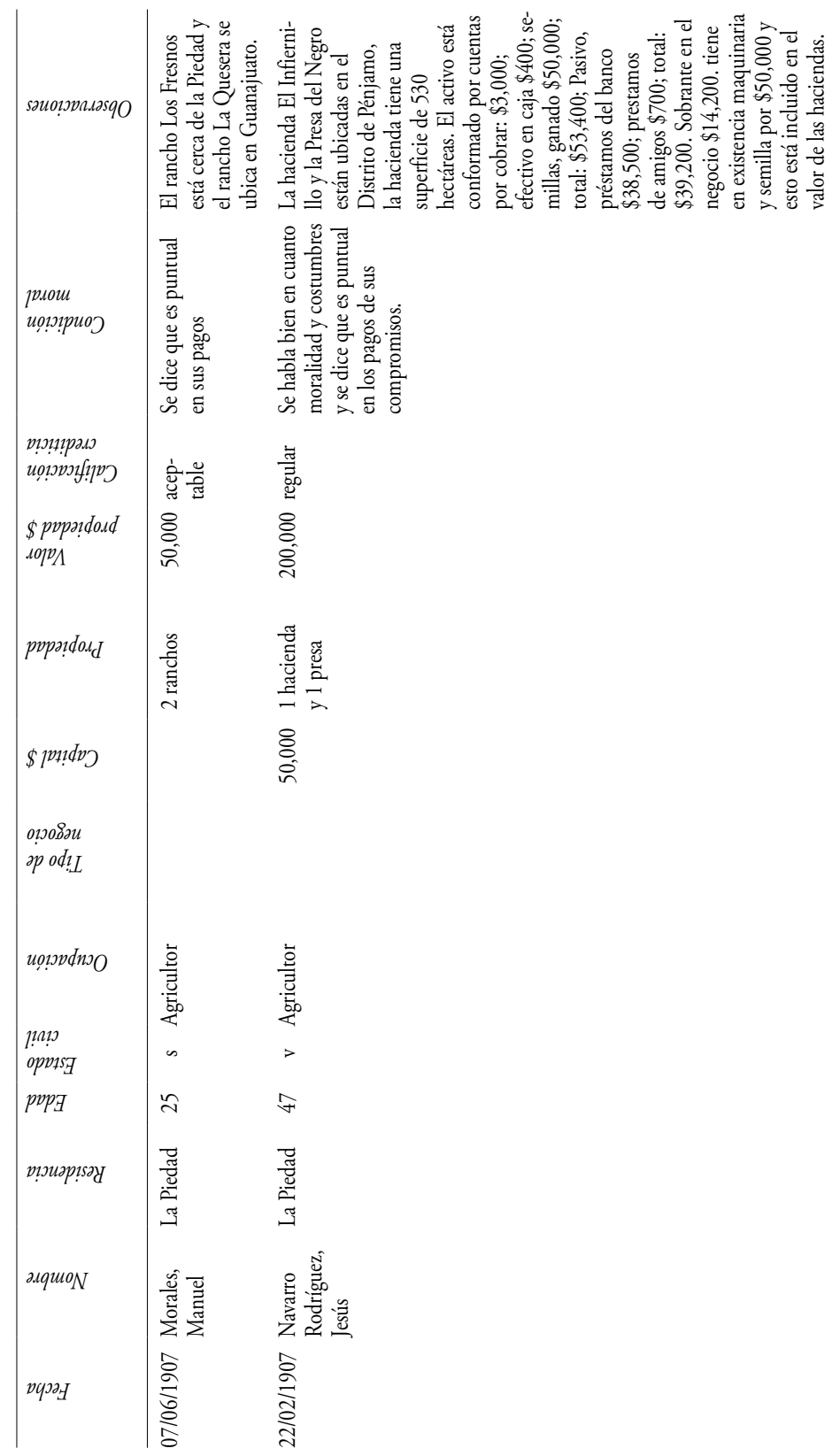



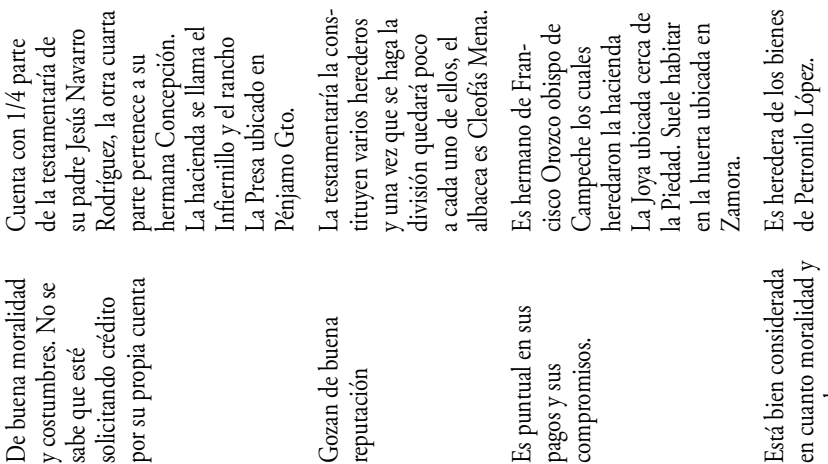

过 $\frac{1}{\pi}$
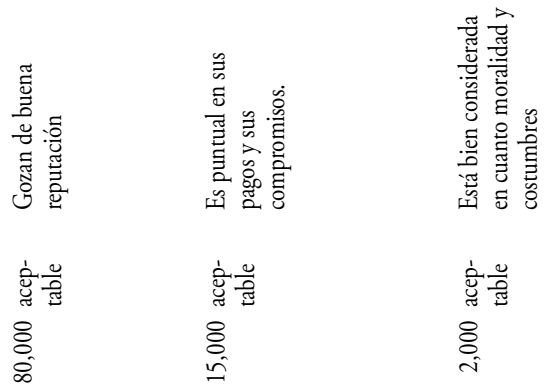

흘둘

홀물

응

ㅇํㅇ
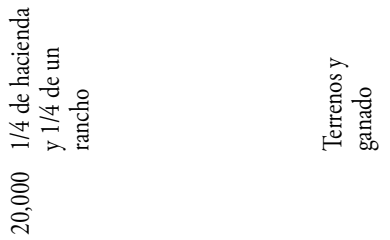

ช

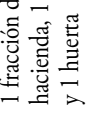

8̊ㅇㅇㅇㅇ

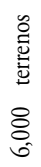

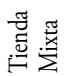

$\frac{\overrightarrow{9}}{\frac{0}{0}}$

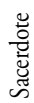

䒕

ㅇํ

พ

ఫ⿱艹

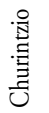

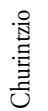
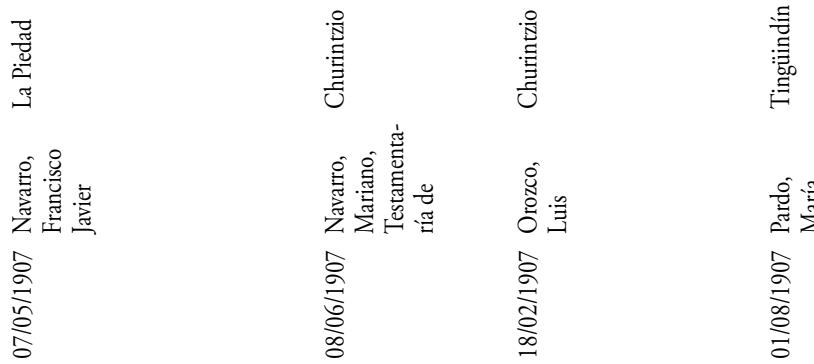

今.

芯

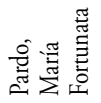

ڤे

ڤ్

ڤे 


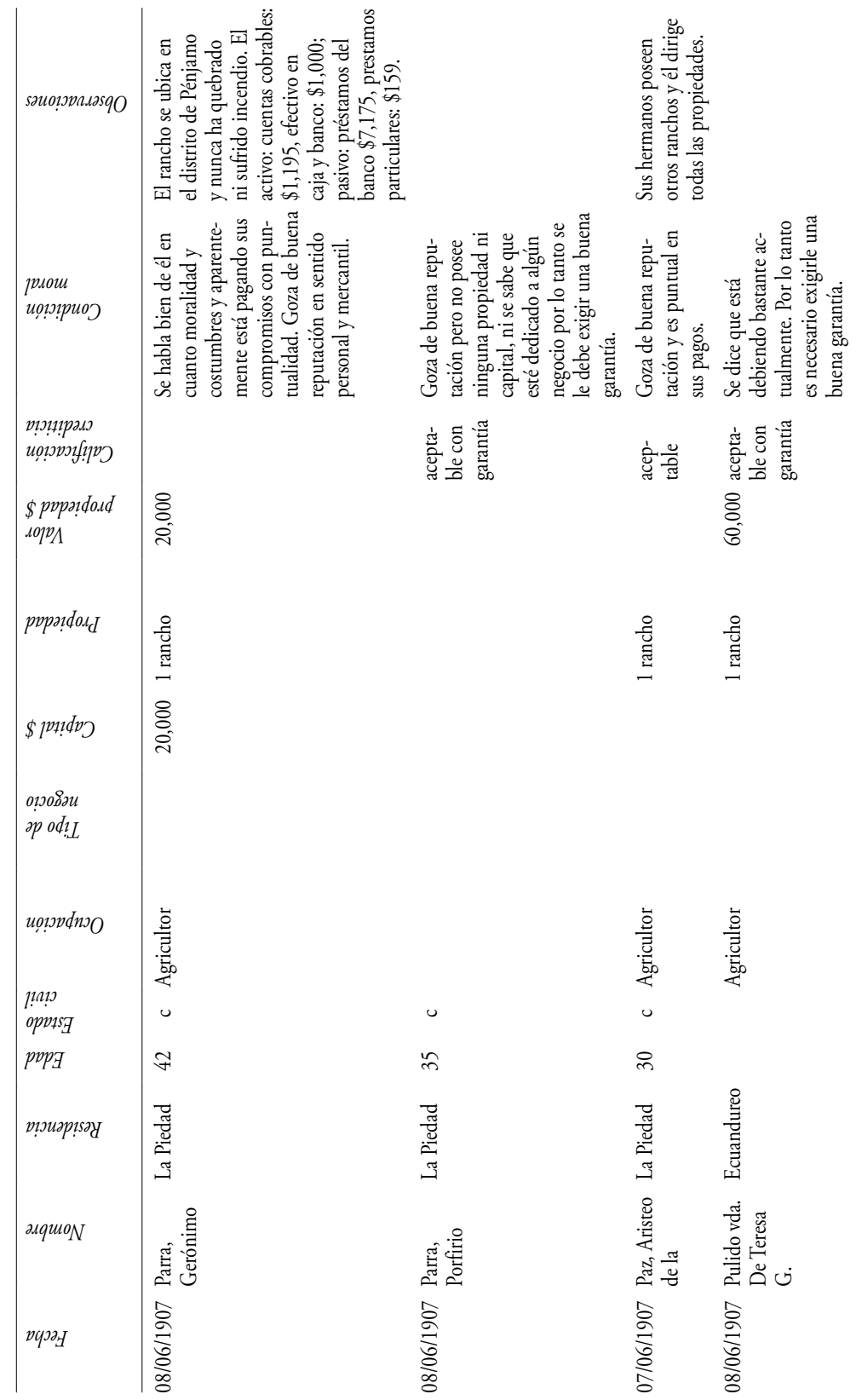



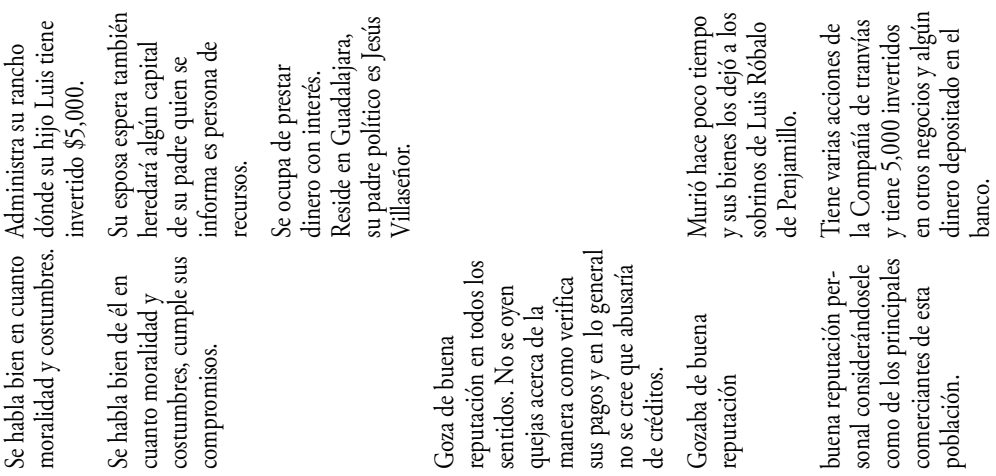

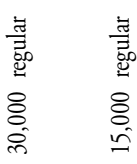
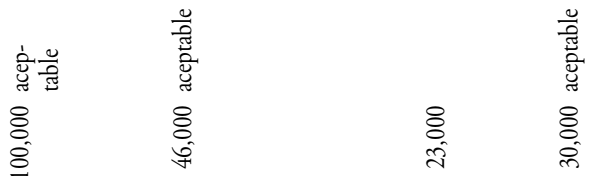

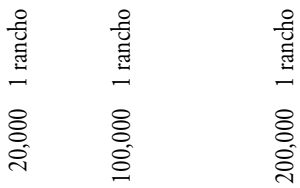

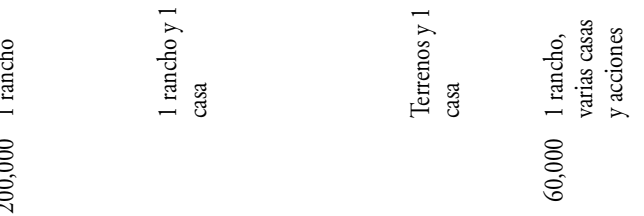

용

苍

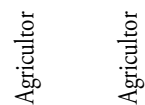

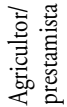

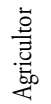

芯

요 $\quad$ ㅇ

$>$

\& 00

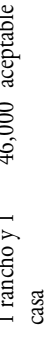

ᄋ̊ㅇㅇ

ᄋ్

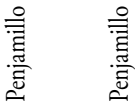

蓑

$\stackrel{\text { in }}{n}$

ㅇำ

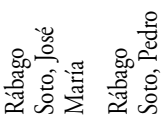

苗

苞

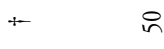

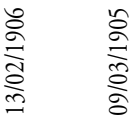

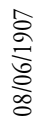

宅 它

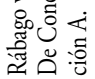

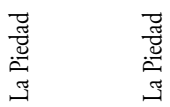

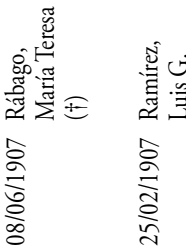

Relaciones 146 , primavera 2016, pp. 121-158, ISSN 0185-3929 


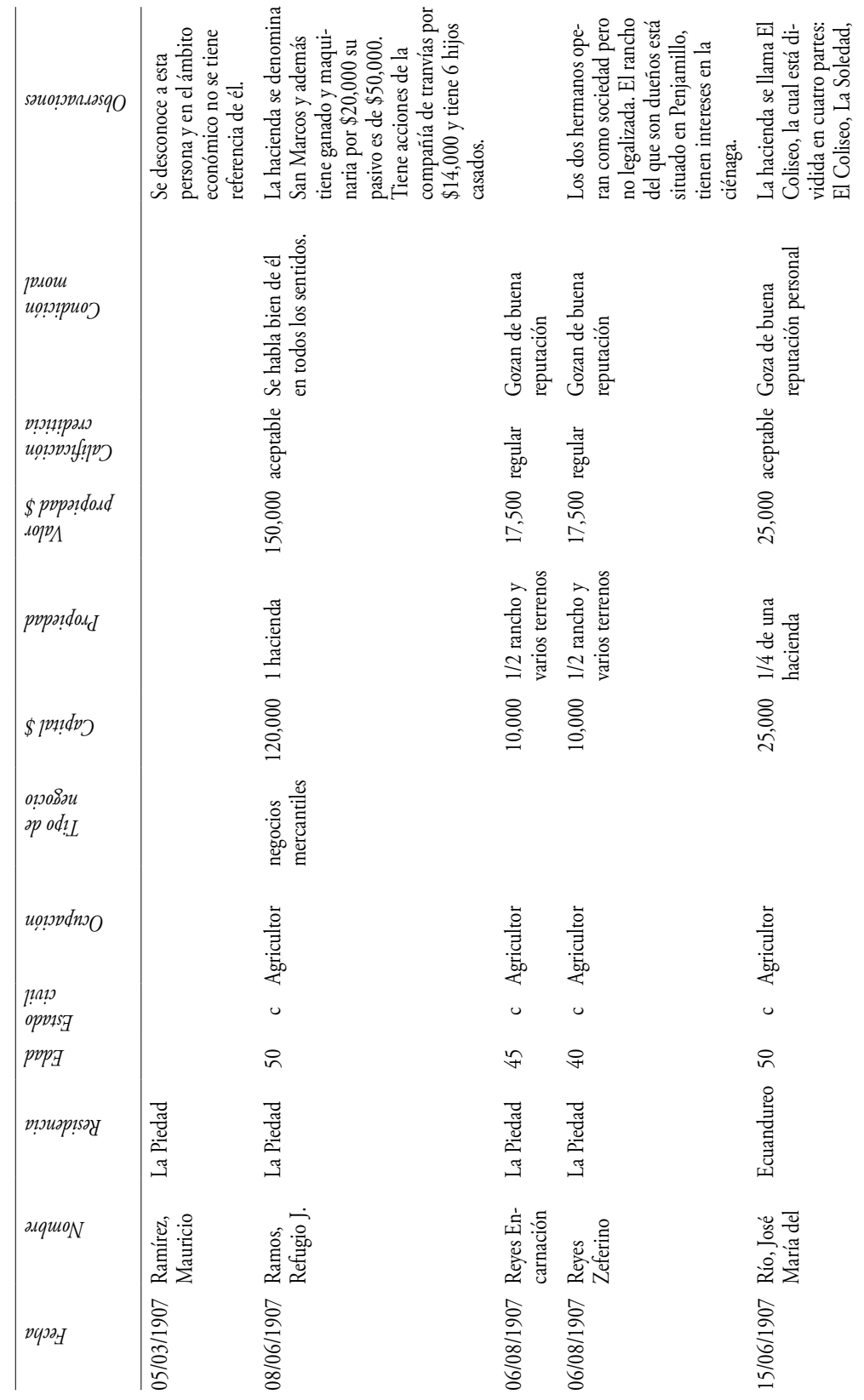




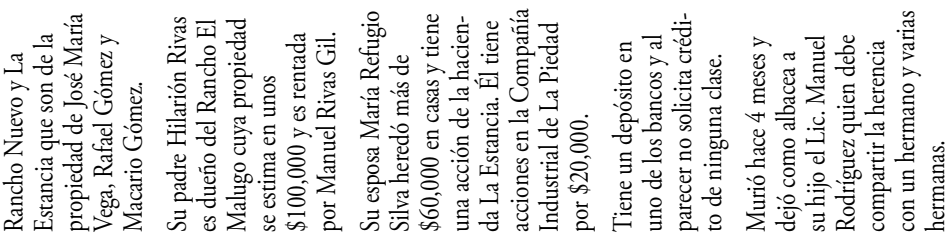

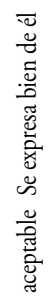
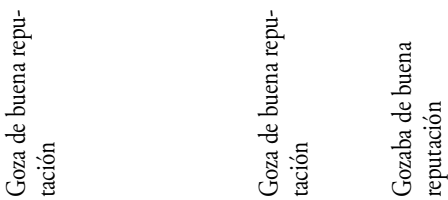

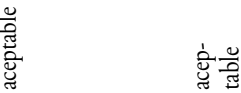

离

这

हี艹

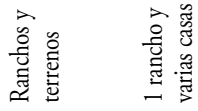

\&े

$\stackrel{8}{8}$

$\stackrel{8}{\circ}$

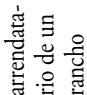

$\frac{\overrightarrow{0}}{\overrightarrow{3}}$

$\frac{8}{\stackrel{3}{*}}$

$\frac{\text { to }}{\vec{z}}$

우

nิ

$\stackrel{\Re}{\forall}$

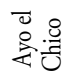

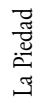

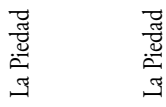

تే छ

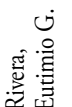

穿

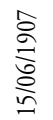

홍

올

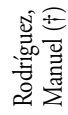

응

高 


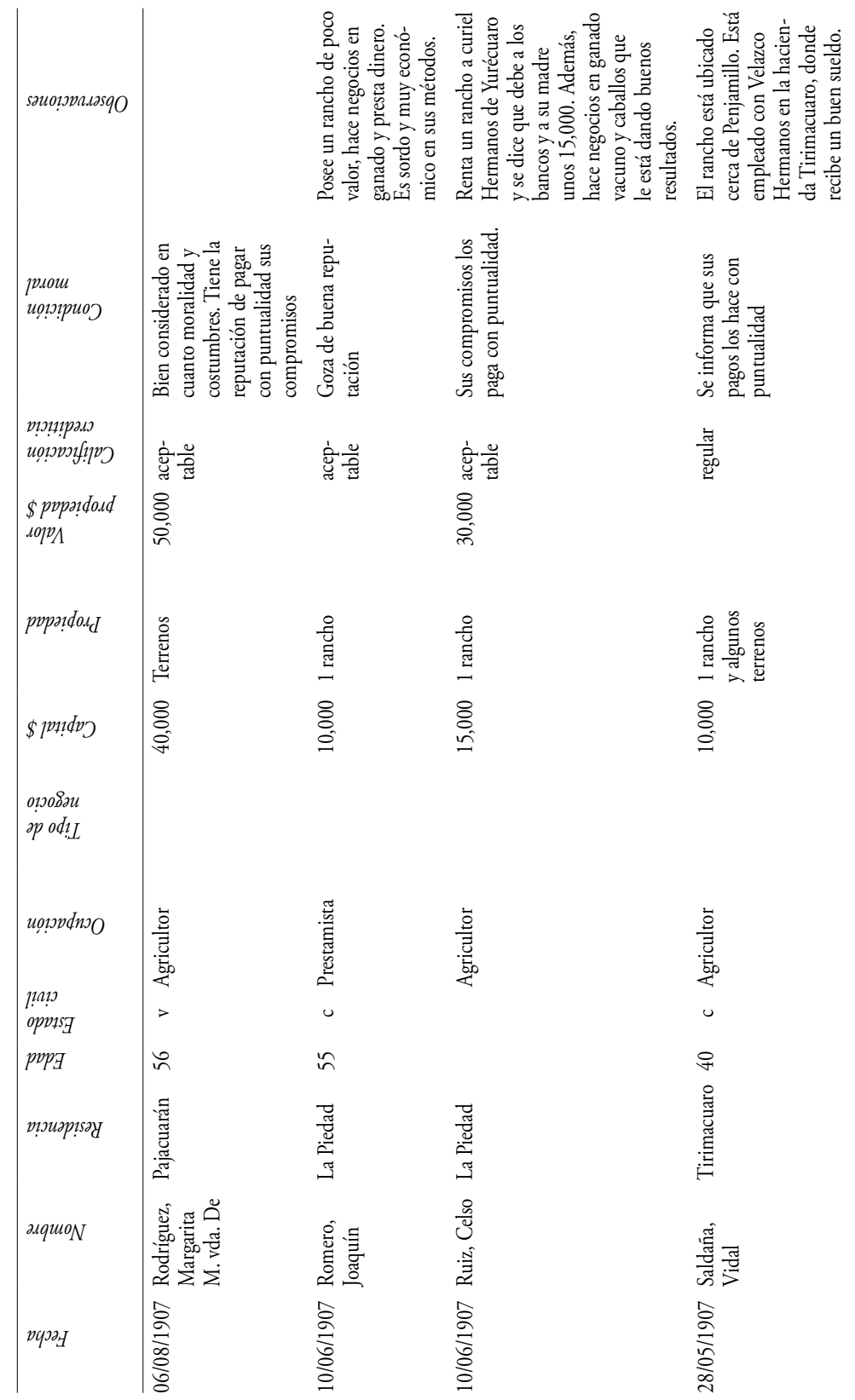




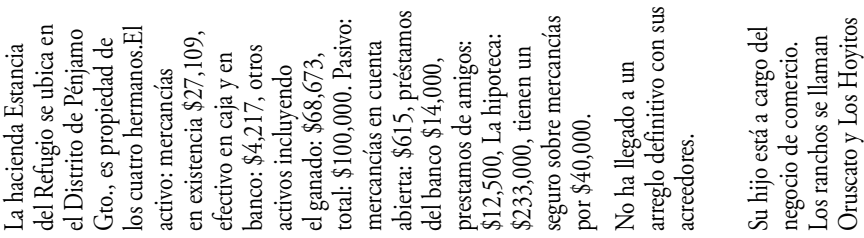

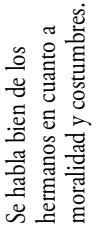

홇

8
8
8
$\circ$

胥

용

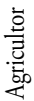

ত্ّ

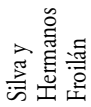

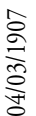

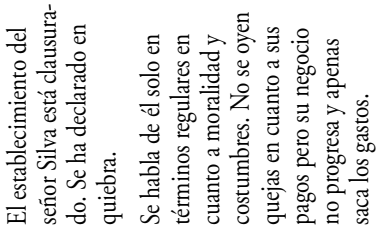

离节 芯

을

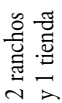

용

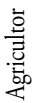

ก

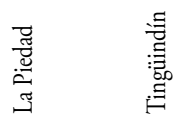

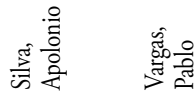

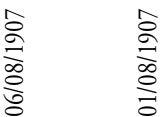




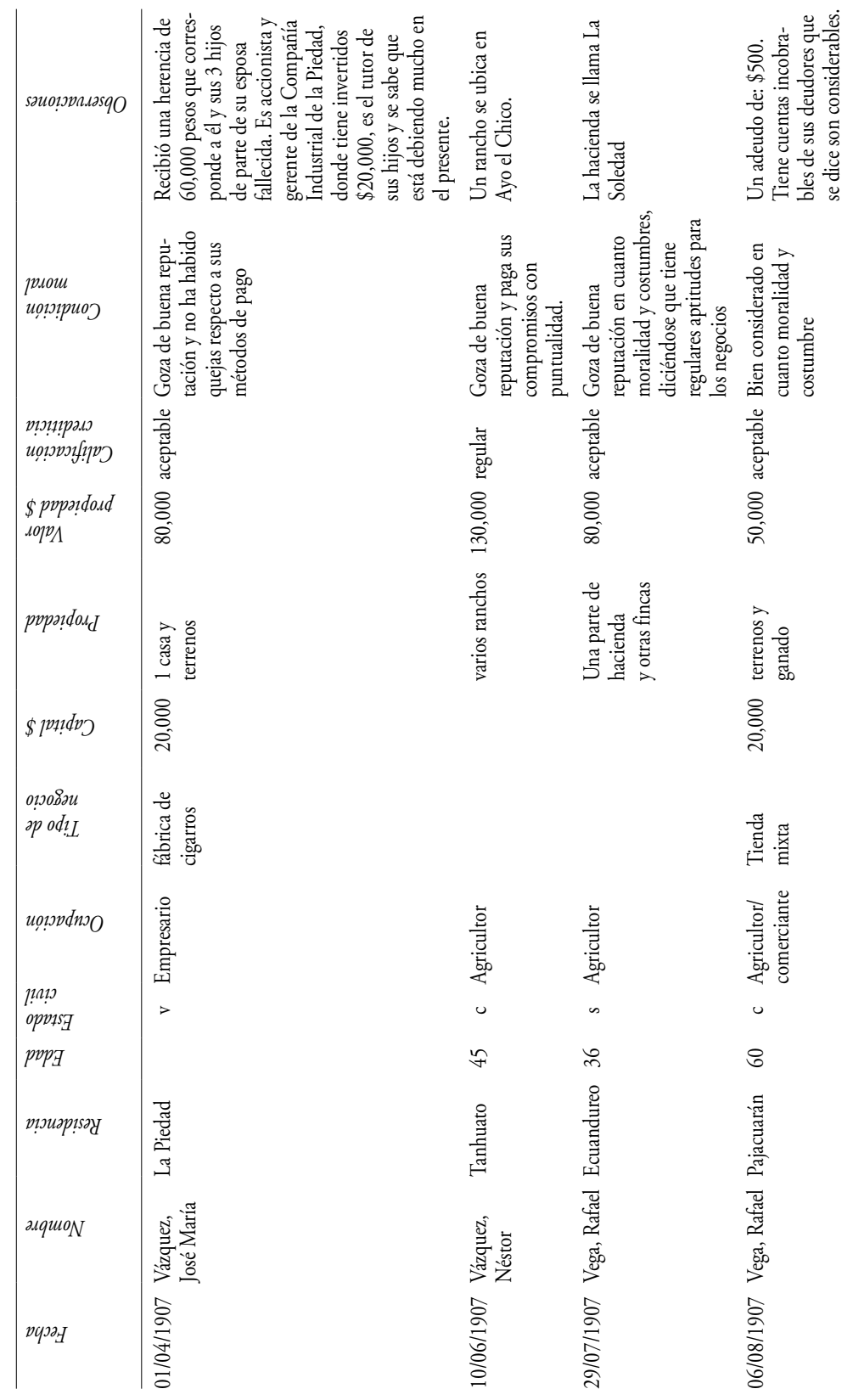




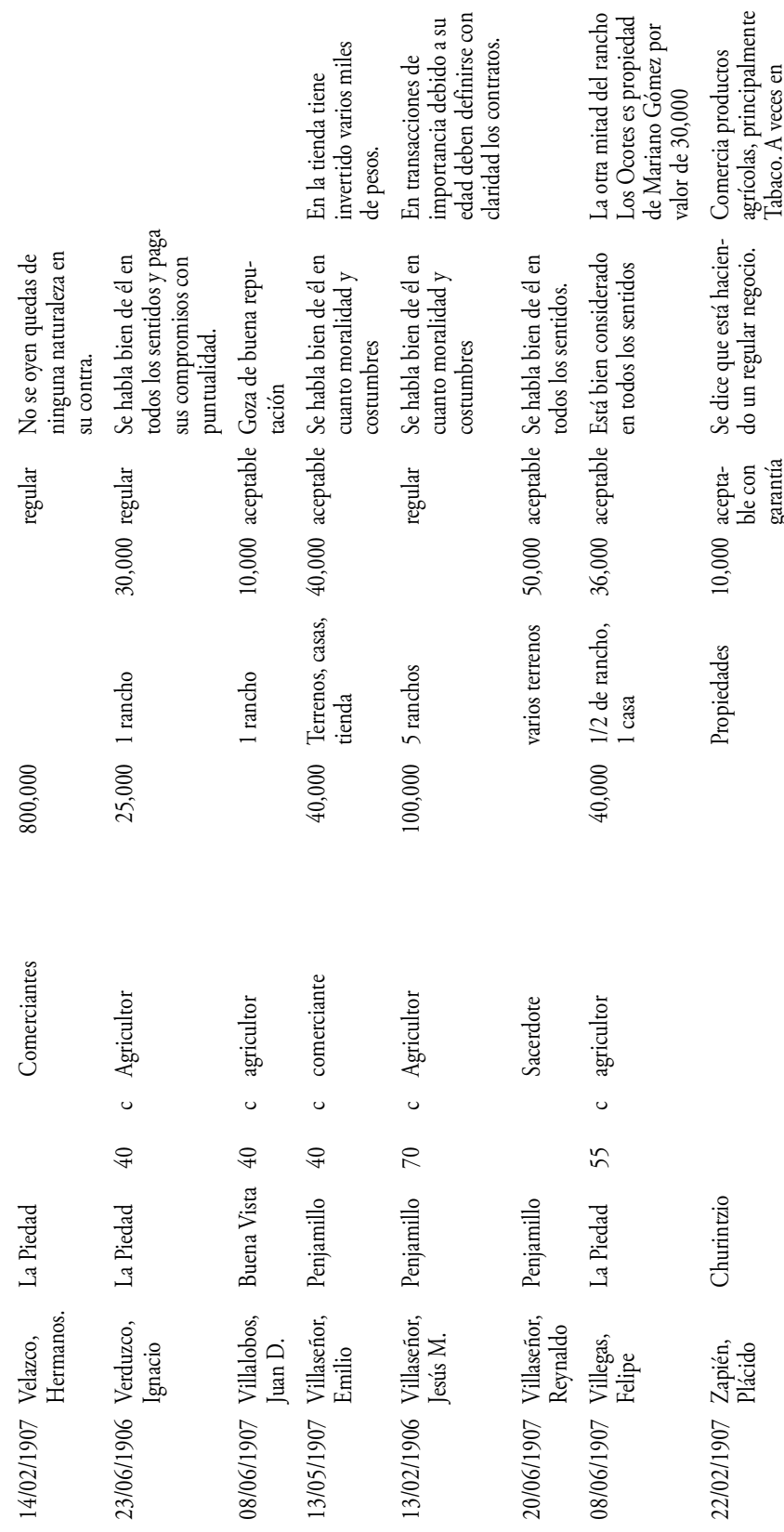




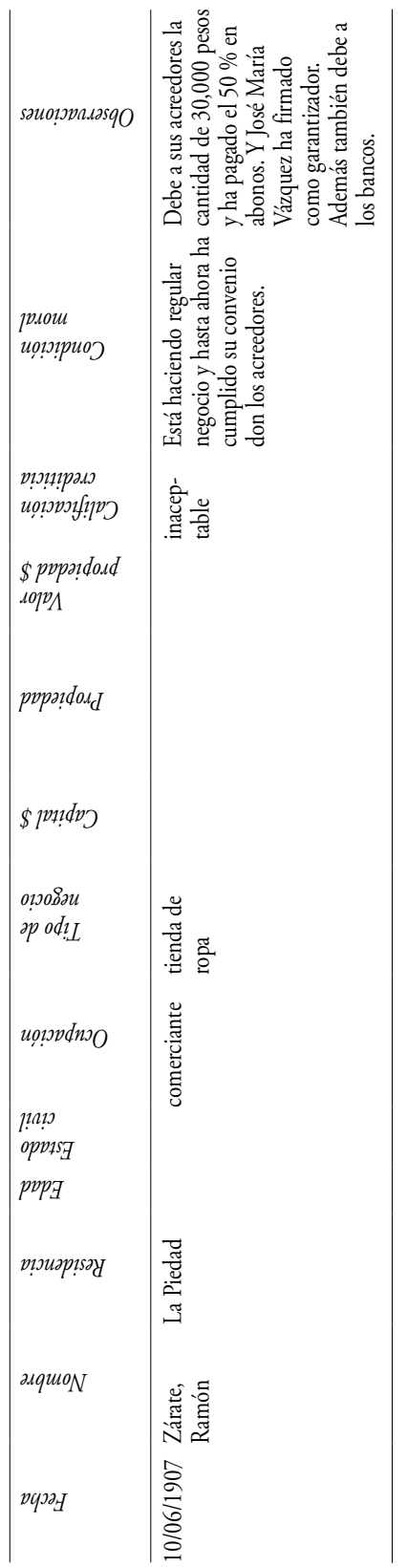

